BMC

Genomics

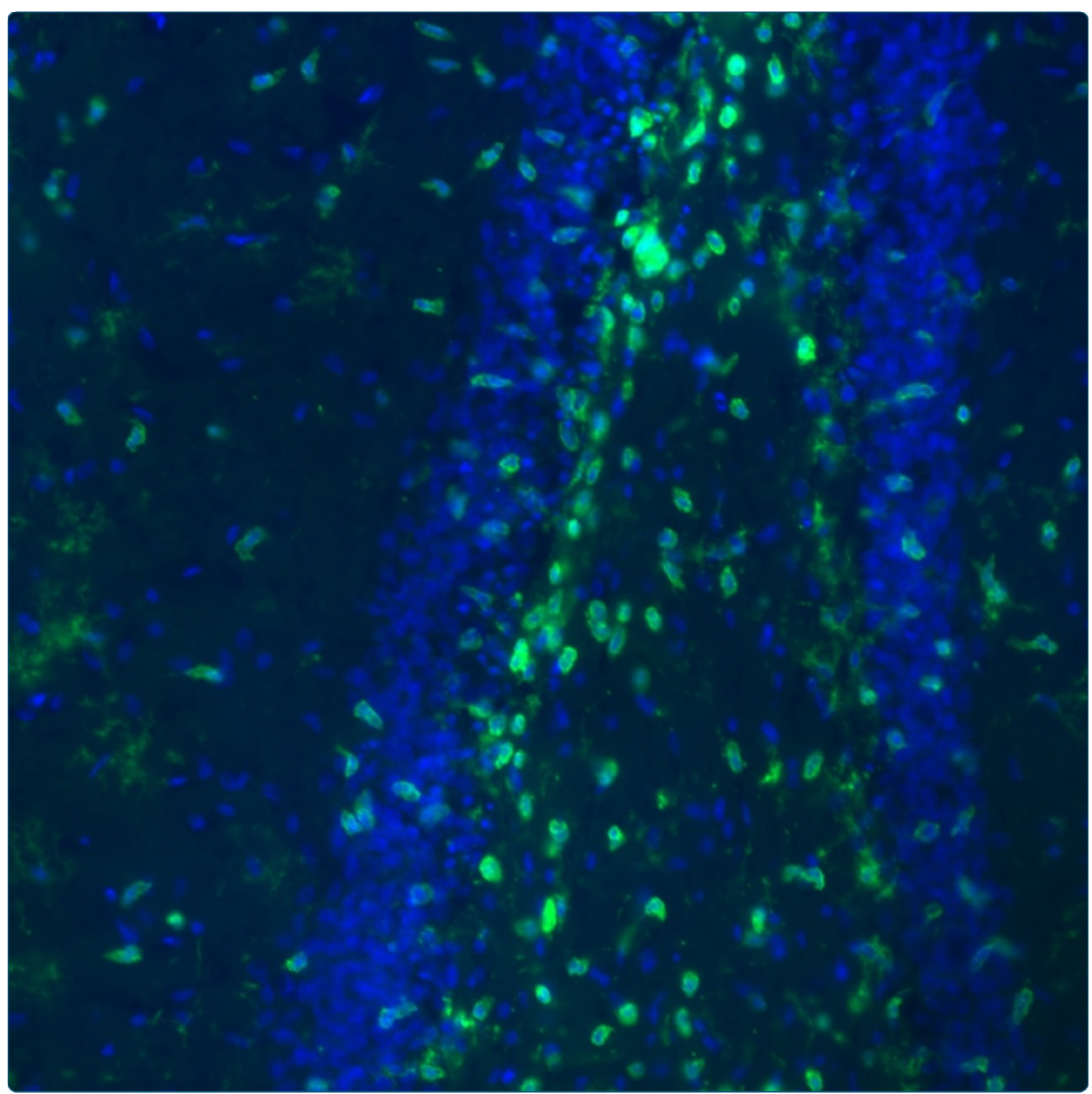

Gene expression patterns following unilateral traumatic brain injury reveals a local pro-inflammatory and remote anti-inflammatory response

White et al. 


\title{
Gene expression patterns following unilateral traumatic brain injury reveals a local pro-inflammatory and remote anti-inflammatory response
}

Todd E White', Gregory D Ford², Monique C Surles-Zeigler ${ }^{1}$, Alicia S Gates', Michelle C LaPlaca ${ }^{3}$ and Byron D Ford ${ }^{1 *}$

\begin{abstract}
Background: Traumatic brain injury (TBI) results in irreversible damage at the site of impact and initiates cellular and molecular processes that lead to secondary neural injury in the surrounding tissue. We used microarray analysis to determine which genes, pathways and networks were significantly altered using a rat model of TBl. Adult rats received a unilateral controlled cortical impact $(\mathrm{CCl})$ and were sacrificed $24 \mathrm{~h}$ post-injury. The ipsilateral hemi-brain tissue at the site of the injury, the corresponding contralateral hemi-brain tissue, and naïve (control) brain tissue were used for microarray analysis. Ingenuity Pathway Analysis (IPA) software was used to identify molecular pathways and networks that were associated with the altered gene expression in brain tissues following TBI.

Results: Inspection of the top fifteen biological functions in IPA associated with TBI in the ipsilateral tissues revealed that all had an inflammatory component. IPA analysis also indicated that inflammatory genes were altered on the contralateral side, but many of the genes were inversely expressed compared to the ipsilateral side. The contralateral gene expression pattern suggests a remote anti-inflammatory molecular response. We created a network of the inversely expressed common (i.e., same gene changed on both sides of the brain) inflammatory response (IR) genes and those IR genes included in pathways and networks identified by IPA that changed on only one side. We ranked the genes by the number of direct connections each had in the network, creating a gene interaction hierarchy $(\mathrm{GIH})$. Two well characterized signaling pathways, toll-like receptor/NF-kappaB signaling and JAK/STAT signaling, were prominent in our GIH.

Conclusions: Bioinformatic analysis of microarray data following TBI identified key molecular pathways and networks associated with neural injury following TBI. The GIH created here provides a starting point for investigating therapeutic targets in a ranked order that is somewhat different than what has been presented previously. In addition to being a vehicle for identifying potential targets for post-TBI therapeutic strategies, our findings can also provide a context for evaluating the potential of therapeutic agents currently in development.
\end{abstract}

Keywords: Bioinformatics, Cytokine, Gene interaction hierarchy, Inflammation, Microarray, Rat, Traumatic brain injury

\footnotetext{
*Correspondence: bford@msm.edu

${ }^{1}$ Department of Neurobiology, Neuroscience Institute, Morehouse School of Medicine, 720 Westview Drive SW, Atlanta, GA 30310, USA

Full list of author information is available at the end of the article
} 


\section{Background}

It is estimated that 3.17-3.32 million persons in the United States are living with long-term or lifelong effects of traumatic brain injury (TBI) [1]. Approximately 1.7 million new TBIs are sustained each year [2] resulting in 53,000 deaths [3] and as many as 125,000 additional people that have long-term behavioral deficits [4]. Efforts to implement preventative measures for the leading causes of TBI (motor vehicle-traffic accidents, falls, and assaults) are critical $[2,3]$ but will not eliminate TBI as a major public health problem. Development of effective clinical treatment protocols post-TBI and potential prophylactic agents for military usage are necessary to address those TBIs that cannot be prevented.

Injury to the brain results in irreversible damage at the site of impact and initiates cellular and molecular processes that lead to delayed or secondary neural injury in the surrounding tissue [5,6]. Neuroprotective strategies target these processes in an attempt to halt the progression of or prevent the delayed injury [7]. These processes include inflammation, damage to the blood brain barrier, release of excitatory amino acids, oxidative stress, cerebral edema, reduced cerebral blood flow, hypoxia, and ischemia [5,6]. In the current study, we used gene microarray analysis to determine which genes, pathways and networks were significantly altered after unilateral controlled cortical impact (CCI), an experimental model of TBI.

Microarray technology is a very powerful tool that allows the user to examine expression profiles for thousands of genes at one time. The true power of microarray technology can be maximized when the expression profiles can be attributed to significant alterations in biological functions and molecular pathways. Fortunately, the recent development of advanced bioinformatic analysis tools has made the utilization of microarray data more practical and allows for easier replication. One such tool is the Ingenuity Pathway Analysis (IPA) software program which uses a database built from published scientific literature to draw direct and indirect interactions between genes and to assign genes to specific biological functions and canonical pathways [8]. IPA was used here for functional, canonical pathway, and network analysis of the genes that were altered by TBI. We examined gene expression on both sides of the brain in order to understand the alterations both locally (ipsilateral) and remotely on the opposite side of the brain (contralateral). We observed that the contralateral side of the brain, which has often been used as a control in similar experiments, exhibited significant alterations in gene expression following TBI.

The bioinformatic analysis tools we used also allowed for both identification of key molecules and elucidation of their interactions with each other. We used these interactions to identify molecules and molecular pathways central in the response to TBI that could provide novel targets for therapeutic strategies. Understanding how local and remote gene expression profiles change following TBI, when compared to non-injured brain, will provide valuable insight into delayed neuronal injury mechanisms as well as intrinsic neuroprotective processes.

\section{Results}

\section{Principal component analysis}

The ipsilateral, contralateral, and naïve gene datasets generated 24 hours post-TBI were analyzed by principal component analysis (PCA) to assess the variability of our microarray data. Nine principal components were generated and the first 3 principal components explain 91.267\% of the variance in our microarray data. The 3D score plot generated from these identified injury status as the major source of variability (Figure 1A). Similarity between data points in the PCA was determined by the distance between the points, with shorter distance indicating increased similarity. Each data point represents one animal's gene expression profile. Ipsilateral, contralateral and naïve all clustered together by injury status and each group was well isolated from the other two groups.

\section{Functional analysis}

A total of 69 biological functions met IPA's threshold and cutoff conditions for the TBI-I (ipsilateral vs naïve) dataset. Inspection of the top 15 biological functions associated with the dataset in IPA showed that 7 of these functions are explicitly cellular in nature; cellular movement, cellular growth and proliferation, cellular development, cell death, cell cycle, cell morphology, and immune cell trafficking (Figure 1B). Of the other top functions, 5 are disease and disorder related; cancer, neurological disease, genetic disorder, skeletal and muscular disorders, and dermatological diseases and conditions. We posited that the majority of these functional categories had an inflammatory component and inflammatory response (IR) itself was ranked as the 15th most significant biological function for our dataset. To further investigate this, we calculated the percentage of gene overlap each function had with inflammatory response. This overlap ranged from $26 \%$ to $93 \%$ with 9 biological functions falling in the 35\% to 55\% range (Table 1). The cumulative overlap of IR with the other 14 top biological functions was 39.3\%. Therefore, we chose to focus our subsequent analysis techniques on the inflammatory response genes in this study because of the significant involvement of inflammatory genes in all of the top ranked biological functions and the role of the IR in secondary neural injury $[5,6,9,10]$.

\section{Histology and immunohistochemistry}

Histology and immunostaining were used to assess damage to and the inflammatory state of the brain. Figure 2 demonstrates cortical damage to the brain tissue ipsilateral 


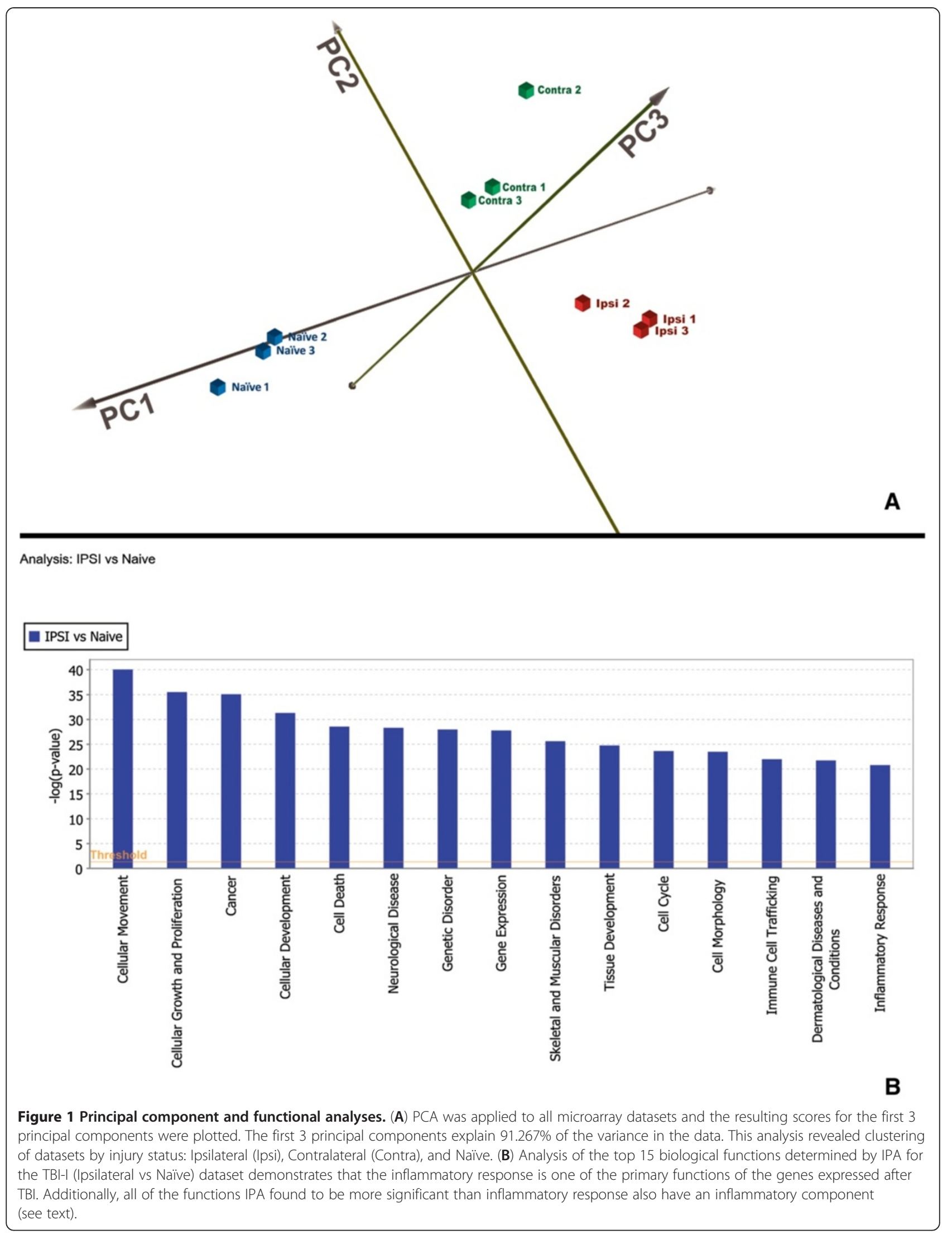


Table 1 Inflammatory nature of top biological functions

\begin{tabular}{lccc}
\hline Biological function & $\begin{array}{c}\text { Unique genes } \\
\text { for function }\end{array}$ & $\begin{array}{c}\text { \# of overlapping } \\
\text { IR genes }\end{array}$ & \% overlap \\
\hline Cellular movement & 381 & 209 & $55 \%$ \\
$\begin{array}{l}\text { Cellular growth and } \\
\text { proliferation }\end{array}$ & 583 & 227 & $39 \%$ \\
Cancer & 663 & 225 & $34 \%$ \\
Cellular development & 499 & 208 & $42 \%$ \\
Cell death & 472 & 202 & $43 \%$ \\
Neurological disease & 663 & 185 & $28 \%$ \\
Genetic disorder & 1023 & 267 & $26 \%$ \\
Gene expression & 441 & 151 & $34 \%$ \\
Skeletal and & 538 & 191 & $36 \%$ \\
muscular disorders & & 203 & $42 \%$ \\
Tissue development & 479 & 111 & $38 \%$ \\
Cell cycle & 296 & 133 & $50 \%$ \\
Cell morphology & 267 & 216 & $94 \%$ \\
Immune cell & 231 & & $55 \%$ \\
trafficking & 268 & & \\
Dermatological & & & \\
diseases \& conditions & & 203 & \\
\hline
\end{tabular}

to the injury by Fluoro-Jade B (FJB) and DAPI staining (Figure 2A,C). Near the site of impact, the integrity of the cortex is disrupted and there is obvious tissue loss. ED-1 immunostaining showed that many activated microglia/macrophages were present in the area of tissue damage (Figure 2D). The contralateral side of the brain showed no overt structural damage or ED-1 immunoreactivity (Figure 2B,E,F).

The hippocampal region did not display overt structural damage on either side of the brain (Figure 3C,F) but did show cellular damage ipsilaterally when stained with FJB (Figure 3A). ED-1 staining similarly showed only macrophage/microglial activation in the hippocampus on the ipsilateral side of the brain (Figure 3D). No cortical or hippocampal labeling was seen in negative control sections (data not shown). Any apparent staining in the contralateral hemisphere represented autofluorescence and was similar to levels detected in negative controls.

In contrast to ED-1, CD11b stains all microglia regardless of activation state. When the microglia transform into activated macrophages they also undergo a morphological transformation from a resting ramified state to an

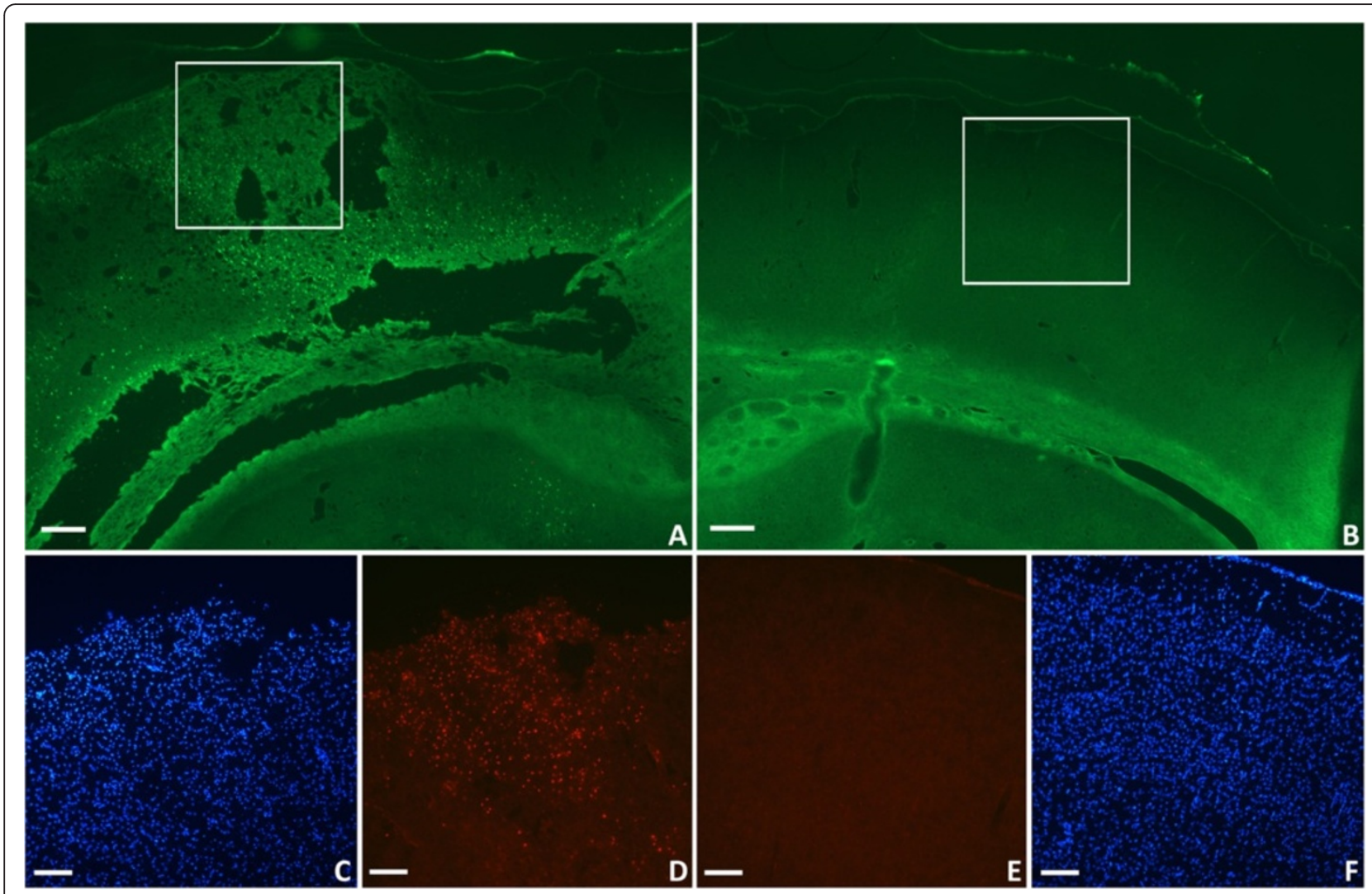

Figure 2 Cortical histology following TBI. Damage to the ipsilateral cortex is demonstrated by FJB staining (A). FJB staining is absent in the contralateral cortex $(\mathbf{B})$, consistent with the lack of trauma. The damaged cortex $(\mathbf{C})$ contains many macrophages and activated microglia as demonstrated by ED-1 immunostaining (D). There were no activated macrophages in the contralateral cortex (E) and the brain anatomy appears intact (F). FJB: green; DAPI: blue; ED-1: red; Scale bars: $250 \mu \mathrm{m}(\mathbf{A}, \mathbf{B}), 125 \mu \mathrm{m}(\mathbf{C}-\mathbf{F})$. 


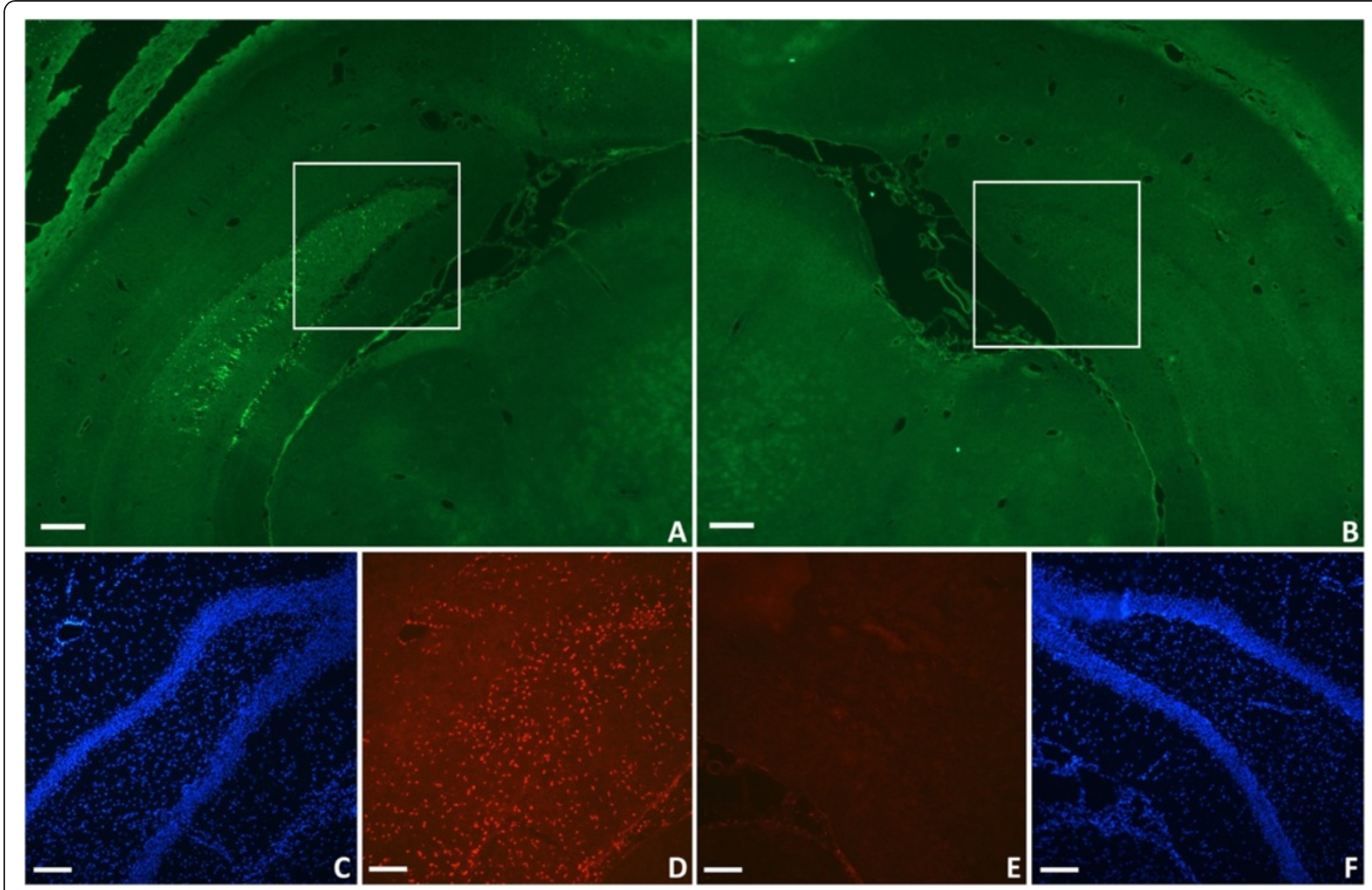

Figure 3 Hippocampal region histology following TBI. Damage to the ipsilateral hippocampal region was demonstrated by FJB staining (A). FJB staining was absent in the contralateral hippocampal region (B). While the integrity of the hippocampus appears intact ipsilaterally (C), many activated microglia and macrophages were present as demonstrated by ED-1 immunostaining (D). There were no activated macrophages in the contralateral hippocampal region $(\mathbf{E})$ and the anatomical structure appears intact (F). FJB: green; DAPI: blue; ED-1: red. Scale bars: $250 \mu \mathrm{m}(\mathbf{A}, \mathbf{B})$, $125 \mu \mathrm{m}(\mathbf{C}-\mathbf{F})$.

amoeboid state. Figure 4 demonstrates that this morphological shift only occurred in areas of cellular damage. There were no amoeboid shaped microglia detected on the contralateral side (Figure 4A,B). Ipsilaterally, both microglial morphologies were observed. Ramified microglia were seen in subcortical regions that did not exhibit cellular damage (Figure 4C) and amoeboid microglia were present at the site of impact (Figure 4D) and in subcortical regions where cellular damage had occurred. This duality can be seen definitively in the ipsilateral hippocampal region where there is cellular damage interspersed between structurally intact tissue (Figure 4E,F). No immunostaining was seen in the cortex or hippocampus in negative control sections (data not shown).

\section{Inflammatory gene expression patterns}

Focusing on the inflammatory response genes in our datasets, we determined that 372 IR genes had a greater than 2-fold change in expression. Of these genes, 146 genes changed on both the ipsilateral and contralateral sides of the brain. In order to determine whether these common genes changed differently on one side of the brain compared to the other, we calculated the ratio of the TBI-I fold change to the TBI-C (contralateral vs naive) fold change. Those genes that had a TBI-I/TBI-C ratio greater than 1.75 were determined to have change differently. We observed that 109 of the common IR genes $(75 \%)$ changed similarly (TBI-I/TBI-C ratio $<1.75$; Figure 5A). Of the genes that changed similarly, 79 genes (54\%) increased in expression and 30 genes (21\%) decreased in expression. The remaining 37 common IR genes (25\%) were changed differently (TBI-I/TBI-C ratio $>1.75$ ) (Figure $5 \mathrm{~A}$ ). Table 2 shows the 37 common IR genes that change differently. These genes span all cellular compartments (extracellular space, plasma membrane, cytoplasm, and nucleus) with diverse molecule types. The expression of all these genes was lower on the contralateral side of the brain. Because of their different expression patterns, these genes became our first group of genes of interest (GOI). Notable genes identified included CCND1, SPP1, ERAP1, LYN, THRA, TIMP1, the transcription regulators STAT3, CEBPD, and CBL, and the plasma membrane receptors and signaling molecules IL6ST, CD44, EGFR, ITGA5, and SDC1. 

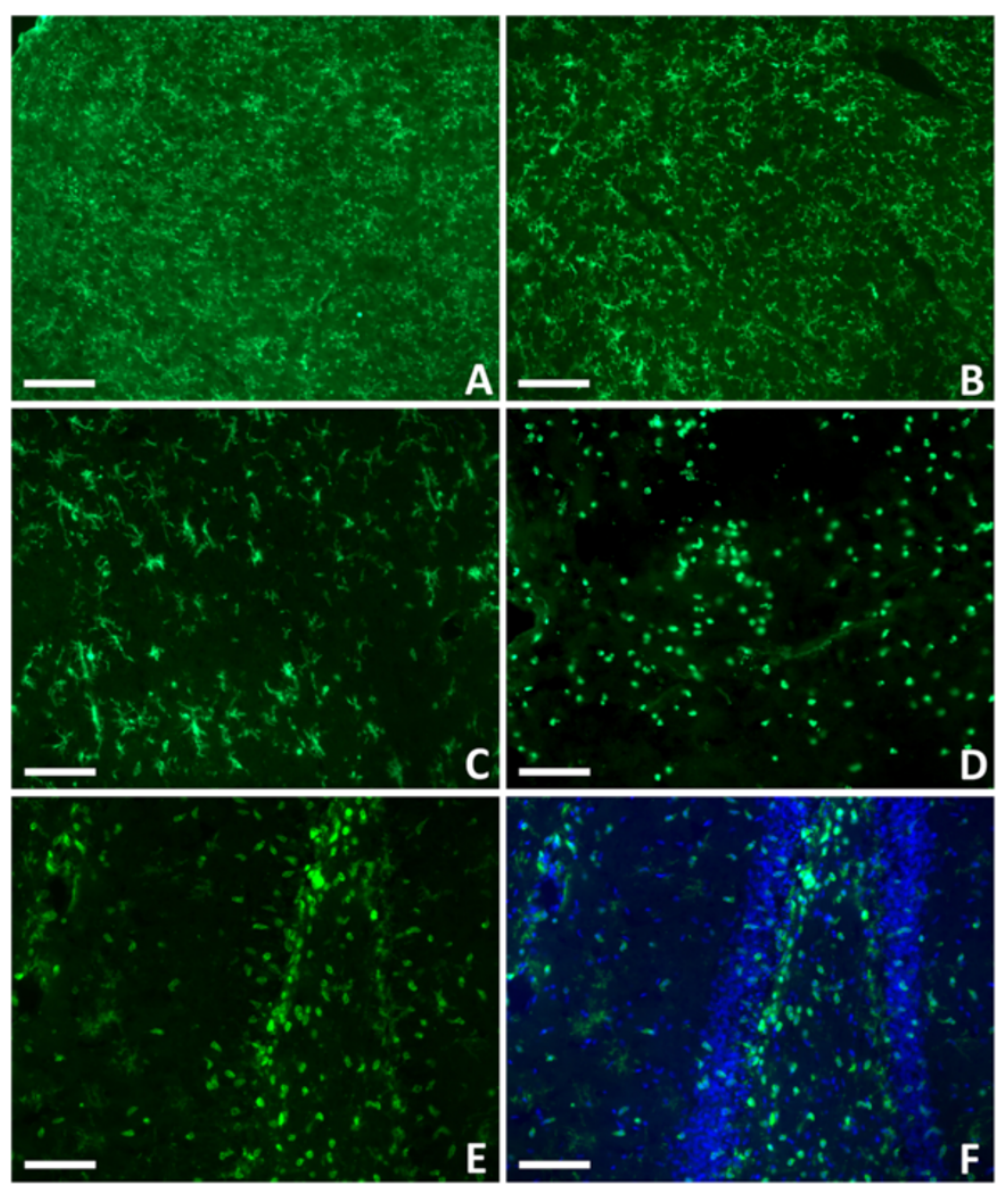

Figure 4 Microglial activation in the injured brain. CD11b immunostaining demonstrated the ramified resting morphology of microglia on the uninjured, contralateral side of the brain (A \& B). This same morphology was seen on the ipsilateral side of the brain in areas less affected by the trauma (C). In damaged brain regions, the microglia were activated and underwent a morphological change, becoming amoeboid in shape (D). Both morphologies can be seen in the hippocampal region where there are amoeboid microglia in the areas of damage and ramified microglia in the surround $(\mathbf{E})$. The same section was counterstained with DAPI to demonstrate the overall cellular anatomy of the region $(\mathbf{F})$. CD11b: green; DAPl: blue. Scale bars: $200 \mu \mathrm{m}$ (A,B), $100 \mu \mathrm{m}$ (C-F).

There were 188 IR genes that changed uniquely on the ipsilateral side of the brain. 179 of those genes (95\%) increased while 9 genes (5\%) decreased in expression (Figure 5B). Only 38 IR genes change uniquely on the contralateral side of the brain and, in contrast to what we observed on the ipsilateral side, only 10 genes $(26 \%)$ increased while 28 genes (74\%) decreased in expression (Figure 5C).

\section{Canonical pathway analysis}

We used canonical pathway and network analysis in IPA to identify genes in our datasets that were most relevant to the observed IR. Because IPA displays only the relative expression values, we defined GOI, in this context, as those genes that either increased or decreased on one side of the brain and showed no change in expression on the other side or genes that had opposite changes in expression. These genes were easily identified by side- by-side comparison of the canonical pathway and gene networks overlaid with the expression values of the TBI-I and TBI-C IR datasets. Canonical pathways in IPA are well-characterized metabolic and cell signaling pathways derived from information found in specific journal articles, review articles, text books, and KEGG Ligand [11]. Figure 6 shows the IL- 6 signaling canonical pathway. IPA determined that this pathway was highly associated with the TBI-I dataset. Additionally, this pathway also includes elements of IL-1, TNF- $\alpha$, and lipopolysaccharide (LPS) signaling. IL-1 and TNF- $\alpha$ were previously associated with TBI and inflammation [9,12-14] and TBI induced inflammation has been shown to be exacerbated by LPS challenge [15]. By overlaying the relative expression values for all TBI-I IR genes (Figure 6A) and all TBI-C IR genes (Figure 6B), we were able to identify a number of GOI that were increased in TBI-I and were either unchanged or decreased in TBI-C, including IL1B, several 


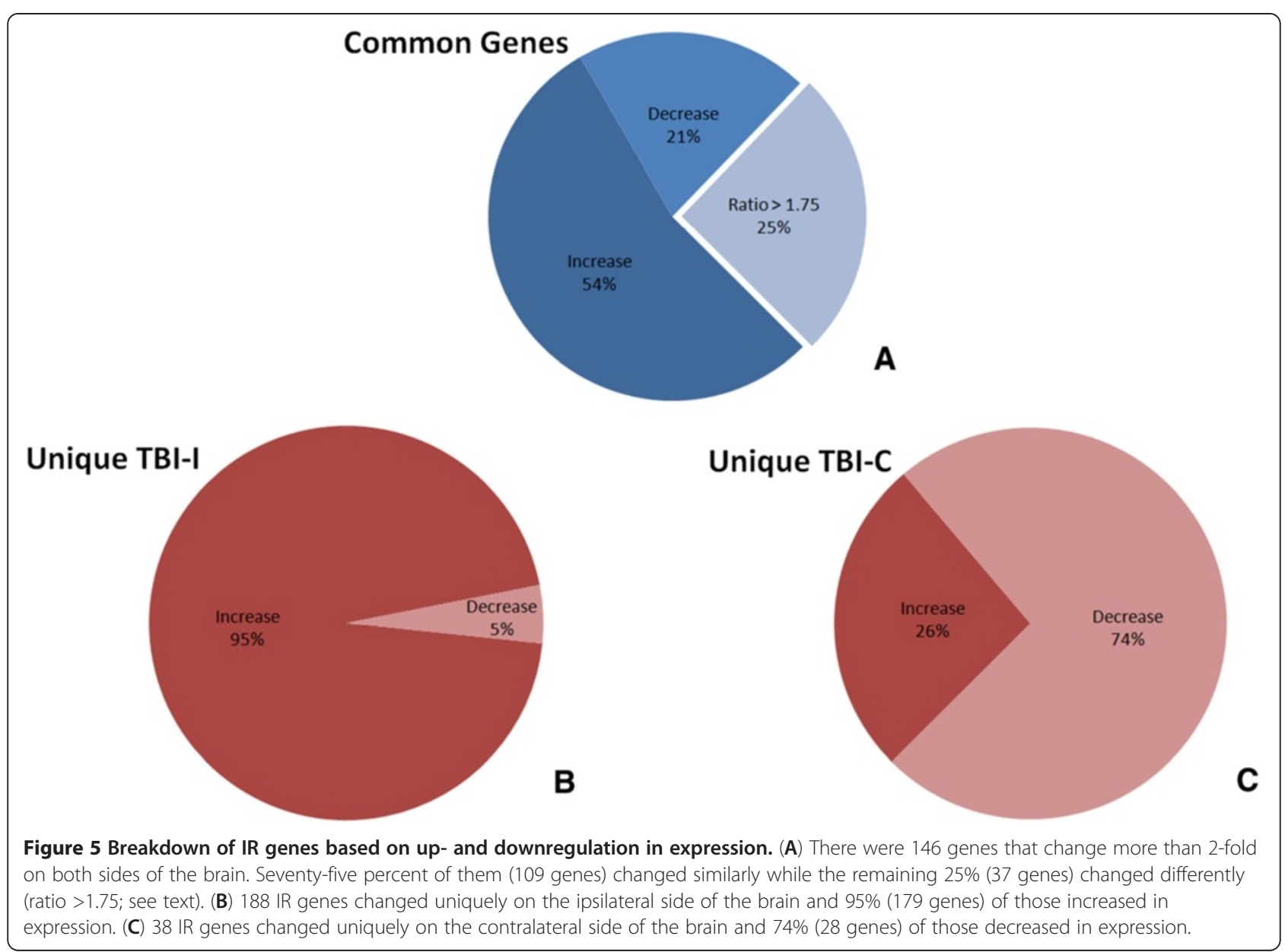

transmembrane cytokine receptors and the transcriptional regulators NFkB, STAT3, CEBPB (NF-IL6), and FOS.

\section{Gene network analysis}

In contrast to canonical pathways, which are relatively immutable in IPA, gene networks are generated de novo in IPA based on the list of genes that are imported. IPA takes "seed" molecules from the gene list, searches the Ingenuity Knowledge Base, and uses a network algorithm to draw connections between molecules based on biological function [16]. In order to generate networks that included IR genes that changed on both sides of the brain, we combined the TBI-I and TBI-C datasets and performed an IPA core analysis on that union dataset. IPA scores the networks in order to rank them according to their degree of relevance to the network eligible molecules in your dataset [16]. Figure 7 shows the highest scored network associated with our union dataset. For this network, we overlaid the relative expression values for the unique TBI-I IR genes (Figure 7A) and unique TBI-C IR genes (Figure 7B) and were able to identify 29 GOI, such as the chemokine CXCL10, a number of cytokine and toll-like receptors, heat shock proteins, and transcriptional regulators that were increased in TBI-I and were either unchanged or decreased in TBI-C. Interestingly, IRF2 was upregulated on the contralateral side of the brain.

Figure 8 shows another network that was scored in the top three networks associated with our union dataset. For this network, we overlaid the relative expression values for all TBI-I IR genes (Figure 8A) and all TBI-C IR genes (Figure $8 \mathrm{~B}$ ) and were able to identify $15 \mathrm{GOI}$ including the cytokine CXCL1, a number of genes in the JAK/STAT pathway, NFkB and several genes associated with apoptosis.

Because the IR is, in part, humoral in nature, we created a network within IPA by seeding it with IR cytokines and growth factors expressed uniquely in the TBI-I dataset and "growing them" (making direct functional connections) to the TBI-I/TBI-C union dataset. Figure 9 shows the resultant network. By overlaying the relative expression values for all TBI-I IR genes (Figure 9A) and all TBI-C IR genes (Figure 9B), we were able to identify 23 more GOI. Notable genes were IL1B, chemokines CCL7, CCL13, CXCL13 and CCL4, peptidases MMP13, 
Table 2 Genes that change differently on each side of the brain

\begin{tabular}{|c|c|c|c|c|c|}
\hline Gene symbol & Entrez gene name & $\begin{array}{l}\text { TBI-I fold } \\
\text { change }\end{array}$ & $\begin{array}{l}\text { TBI-C fold } \\
\text { change }\end{array}$ & $\begin{array}{l}\text { TBI-I/TBI- } \\
\text { C ratio }\end{array}$ & Molecule type \\
\hline \multicolumn{6}{|l|}{$\begin{array}{l}\text { Extracellular } \\
\text { space }\end{array}$} \\
\hline CSF1 & colony stimulating factor 1 (macrophage) & 3.70 & 2.09 & 1.77 & cytokine \\
\hline SPP1 & secreted phosphoprotein 1 & 37.91 & 2.37 & 15.99 & cytokine \\
\hline ERAP1 & endoplasmic reticulum aminopeptidase 1 & 5.84 & 3.05 & 1.92 & peptidase \\
\hline LCN2 & lipocalin 2 & 71.82 & 3.90 & 18.44 & transporter \\
\hline TGFB2 & transforming growth factor, beta 2 & -4.00 & -7.97 & 1.99 & growth factor \\
\hline SERPINA3 & $\begin{array}{l}\text { serpin peptidase inhibitor, clade A (alpha-1 antiproteinase, } \\
\text { antitrypsin), member } 3\end{array}$ & 58.49 & 2.51 & 23.31 & other \\
\hline SERPING1 & serpin peptidase inhibitor, clade G (C1 inhibitor), member 1 & 5.81 & 2.03 & 2.86 & other \\
\hline TIMP1 & TIMP metallopeptidase inhibitor 1 & 38.49 & 2.10 & 18.32 & other \\
\hline \multicolumn{6}{|l|}{$\begin{array}{l}\text { Plasma } \\
\text { membrane }\end{array}$} \\
\hline HLA-C & major histocompatibility complex, class I, C & 9.30 & 3.66 & 2.54 & $\begin{array}{l}\text { transmembrane } \\
\text { receptor }\end{array}$ \\
\hline IGSF6 & immunoglobulin superfamily, member 6 & 22.46 & 3.27 & 6.87 & $\begin{array}{l}\text { transmembrane } \\
\text { receptor }\end{array}$ \\
\hline IL13RA1 & interleukin 13 receptor, alpha 1 & 4.53 & 2.27 & 1.99 & $\begin{array}{l}\text { transmembrane } \\
\text { receptor }\end{array}$ \\
\hline IL6ST & interleukin 6 signal transducer (gp130, oncostatin M receptor) & 2.31 & -3.28 & 7.57 & $\begin{array}{l}\text { transmembrane } \\
\text { receptor }\end{array}$ \\
\hline THBD & thrombomodulin & 3.85 & 2.09 & 1.84 & $\begin{array}{l}\text { transmembrane } \\
\text { receptor }\end{array}$ \\
\hline KCNN4 & $\begin{array}{l}\text { potassium intermediate/small conductance calcium-activated } \\
\text { channel, subfamily N, member } 4\end{array}$ & 3.09 & -9.43 & 29.12 & ion channel \\
\hline EGFR & epidermal growth factor receptor & 6.77 & 2.37 & 2.85 & kinase \\
\hline MGLL & monoglyceride lipase & -7.85 & -18.15 & 2.31 & enzyme \\
\hline CD44 & CD44 molecule (Indian blood group) & 15.56 & 2.40 & 6.49 & other \\
\hline CLEC12A & C-type lectin domain family 12 , member $A$ & 10.92 & 2.15 & 5.08 & other \\
\hline ITGA5 & integrin, alpha 5 (fibronectin receptor, alpha polypeptide) & 4.83 & 2.68 & 1.80 & other \\
\hline SDC1 & syndecan 1 & 13.68 & 2.57 & 5.33 & other \\
\hline \multicolumn{6}{|l|}{ Cytoplasm } \\
\hline LYN & v-yes-1 Yamaguchi sarcoma viral related oncogene homolog & 6.94 & 3.78 & 1.84 & kinase \\
\hline PDE4B & phosphodiesterase 4B, CAMP-specific & 5.60 & 2.36 & 2.37 & enzyme \\
\hline PTPN4 & $\begin{array}{c}\text { protein tyrosine phosphatase, non-receptor type } 4 \\
\text { (megakaryocyte) }\end{array}$ & 4.49 & 2.21 & 2.03 & phosphatase \\
\hline RASA1 & RAS p21 protein activator (GTPase activating protein) 1 & 2.39 & -2.11 & 5.04 & transporter \\
\hline HSPB1 & heat shock 27 kDa protein 1 & 46.92 & 2.64 & 17.78 & other \\
\hline LCP1 & lymphocyte cytosolic protein 1 (L-plastin) & 6.08 & 2.80 & 2.17 & other \\
\hline LSP1 & lymphocyte-specific protein 1 & 11.72 & 2.14 & 5.47 & other \\
\hline MYO1F & myosin IF & 4.27 & 2.26 & 1.89 & other \\
\hline
\end{tabular}

Nucleus

$\begin{array}{cccccc}\text { CBL } & \text { Cas-Br-M (murine) ecotropic retroviral transforming sequence } & -3.40 & -6.13 & 1.80 & \text { transcription regulator } \\ \text { CEBPD } & \text { CCAAT/enhancer binding protein (C/EBP), delta } & 11.27 & 2.04 & 5.53 & \text { transcription regulator } \\ \text { DEK } & \text { DEK oncogene } & -3.01 & -7.35 & 2.45 & \text { transcription regulator } \\ \text { STAT3 } & \text { signal transducer and activator of transcription 3 (acute-phase } & 4.22 & -3.77 & 15.91 & \text { transcription regulator }\end{array}$


Table 2 Genes that change differently on each side of the brain (Continued)

\begin{tabular}{|c|c|c|c|c|c|}
\hline MX1 & $\begin{array}{l}\text { myxovirus (influenza virus) resistance 1, interferon-inducible } \\
\text { protein p78 (mouse) }\end{array}$ & 28.18 & 7.33 & 3.85 & enzyme \\
\hline TOP2A & topoisomerase (DNA) II alpha $170 \mathrm{kDa}$ & 2.26 & -2.41 & 5.44 & enzyme \\
\hline THRA & thyroid hormone receptor, alpha & -2.80 & -11.52 & 4.12 & $\begin{array}{l}\text { ligand-dependent } \\
\text { nuclear receptor }\end{array}$ \\
\hline CCND1 & cyclin D1 & 2.15 & -2.03 & 4.36 & other \\
\hline \multicolumn{6}{|l|}{ Unknown } \\
\hline $\begin{array}{l}\text { Slpi (includes } \\
\text { others) }\end{array}$ & secretory leukocyte peptidase inhibitor & 82.91 & 3.12 & 26.58 & other \\
\hline
\end{tabular}

TBI-I/TBI-C Ratio: Gene increased on both sides: ratio = $(\mathrm{TBI}-\mathrm{I}) /(\mathrm{TBI}-\mathrm{C}) ;$ Gene decreased on both sides: ratio $=1 /[(\mathrm{TBI}-\mathrm{I}) /(\mathrm{TBI}-\mathrm{C})]$;

Gene increased ipsilaterally and decreased contralaterally: ratio $=(\mathrm{TBI}-\mathrm{I}) /-[1 /(\mathrm{TBI}-\mathrm{C})]$.

MMP3, and MMP9 and many inflammation associated transcription factors.

\section{Compiling the gene interaction hierarchy (GIH)}

By combining the GOI identified through canonical pathway and network analysis with those in Table 2, we identified a total of 114 GOI. In order to determine which genes might be most relevant in the IR, we ranked these genes relative to each other by the number of direct interactions each had with the other GOI. Our analysis showed that 95 of the GOI formed an interconnected network, leaving 19 "orphan" genes (see Additional file 1). Genes having more than 10 connections ( $1^{\text {st }}$ order) within the main GOI network were considered "primary" in this analysis (see Additional file 2 for an example). Genes having 5-10 connections were considered "secondary" (see Additional file 3 for an example) and those with less than 5 connections were considered "peripheral". The resultant GIH is displayed in Table 3.

\section{Discussion}

In this study, we used microarray technology to examine cellular and molecular mechanisms associated with secondary brain injury following TBI. Our findings indicated that the inflammatory response and its associated genes and pathways are significant in the post-TBI molecular response. This is consistent with our published studies indicating that inflammation is involved with delayed, secondary neuronal injury following other acute brain injuries (ABI's) including stroke and neurotoxin exposure [17-20]. Activated microglia, astrocytes and macrophages have been shown to be the source of several of the inflammatory molecules identified in this study [10,21-23]. The presence of activated inflammatory cells ipsilaterally and their absence contralaterally was confirmed by immunohistochemistry. This cellular inflammation offers further evidence for pro-inflammatory molecules being produced in the region of tissue damage following TBI.

Despite the absence of activated inflammatory cells on the contralateral side of the brain, our results also showed that TBI resulted in a significant alteration of the inflammatory gene response on the both sides of the brain. The observed IR gene expression pattern suggests that there is a baseline IR throughout the whole brain due to unilateral CCI. This is demonstrated by the nearly $30 \%$ of all IR genes that change similarly on both sides of the brain (109 of 372 IR genes). Above this baseline of inflammation, a distinct IR gene expression pattern emerges. The expression level is higher on the ipsilateral side for all the remaining genes expressed on both sides of the brain. 95\% of the IR genes expressed only in ipsilateral tissues increase in expression while $74 \%$ of the IR genes expressed only in contralateral tissues decrease in expression. Examination of the contralateral gene expression in our $\mathrm{GIH}$ showed that 11 genes ( 3 primary tier, 3 secondary tier, 3 peripheral tier and 2 orphan) decreased in expression contralaterally while either remaining unchanged or increasing in expression ipsilaterally. Only 3 genes (1 secondary and 2 peripheral tier) increased contralaterally and remained unchanged ipsilaterally. This demonstrated that the most significant contralateral IR genes in this analysis show decreased expression.

Taken together with the cellular inflammation data, we can surmise that increased expression of the majority of IR genes ipsilaterally results in the development of functional inflammation that can contribute to secondary neural injury. Similarly, it is likely that the suppression of the majority of IR genes contralaterally prevents this development in brain regions remote to the injury. This summary of the overall IR gene expression does not take into account that some IR genes may be classified as anti-inflammatory in certain contexts. However, any counter effects of anti-inflammatory molecules seems to be negligible as the cellular inflammation pattern follows the IR gene expression pattern assuming the majority of IR genes are pro-inflammatory. The contralateral inflammatory response without detectable cellular inflammation also fits well with the idea that some inflammation may actually be beneficial following TBI [9].

Through canonical pathway and network analysis combined with identification of the common genes that 

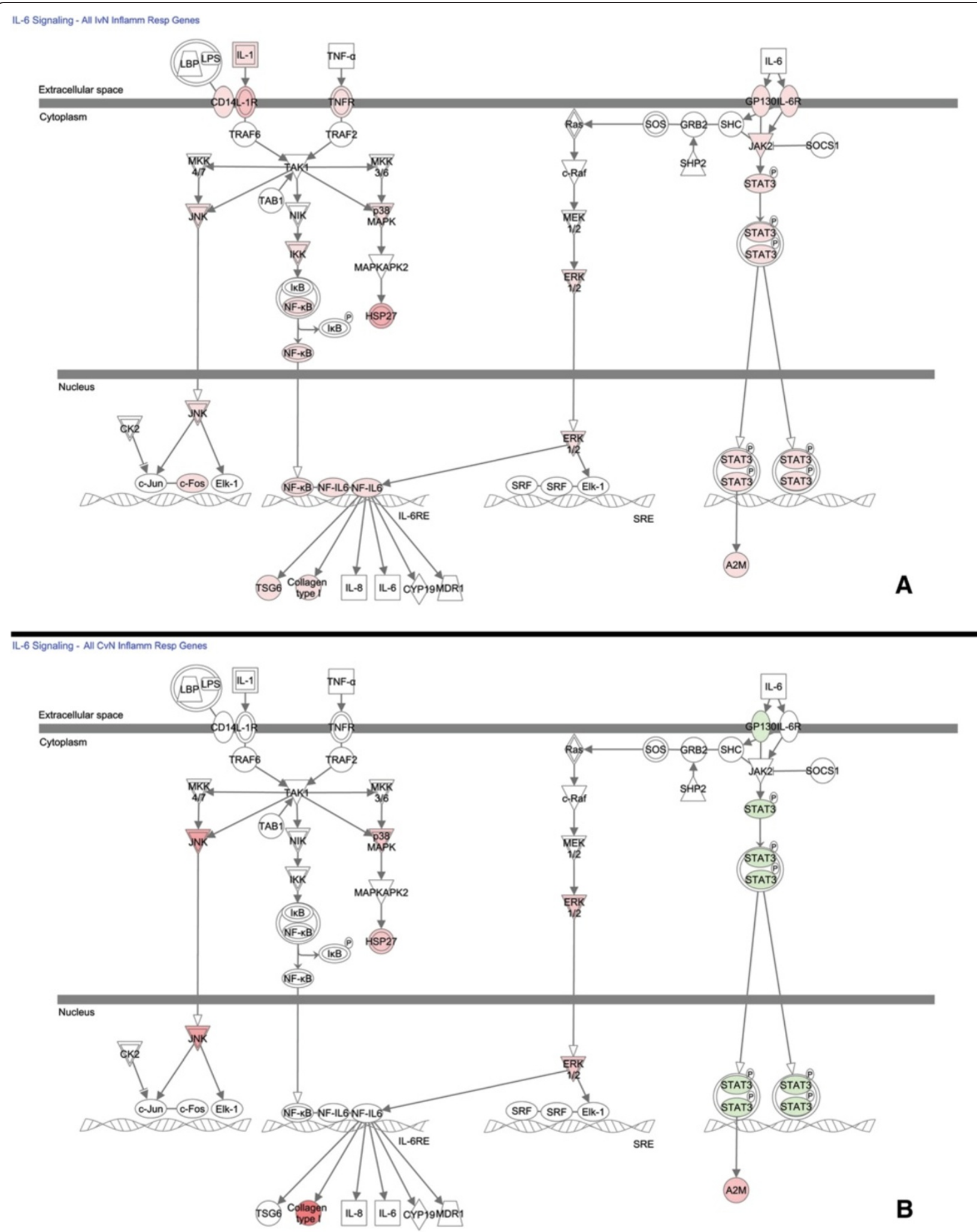

Figure 6 Canonical pathway analysis. The IL-6 signaling pathway showing the relative expression values for all TBI-I IR genes (A) and all TBI-C IR genes (B) involved in this pathway. red: relative increase in expression; green: relative decrease in expression; white: no change in expression. 


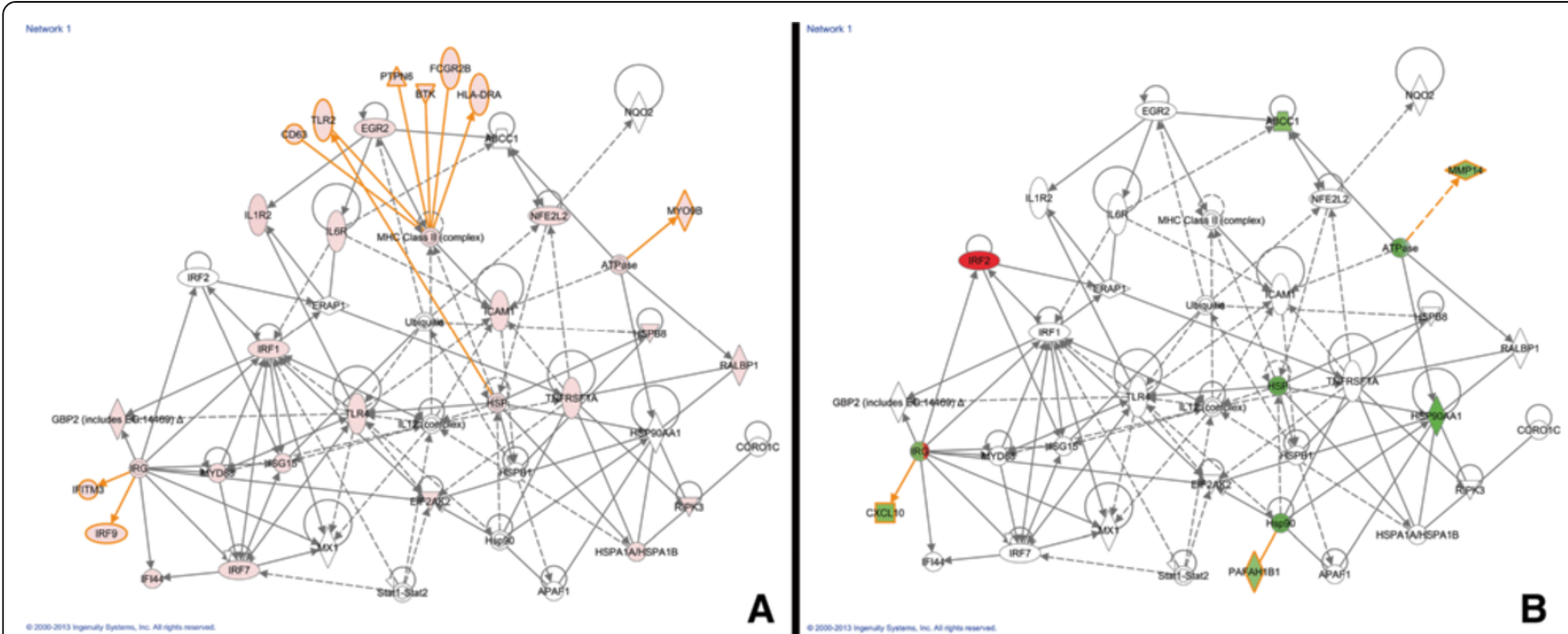

Figure 7 Analysis of the highest scored IPA generated gene network. This was the highest scored gene network associated with the TBI-I/ TBI-C union dataset. The relative expression values of the unique TBI-I IR genes (A) and unique TBI-C IR genes (B) included in this network are shown. red: relative increase in expression; green: relative decrease in expression; white: no change in expression; orange connections and outlines: direct connections with gene groups and complexes in the original network.

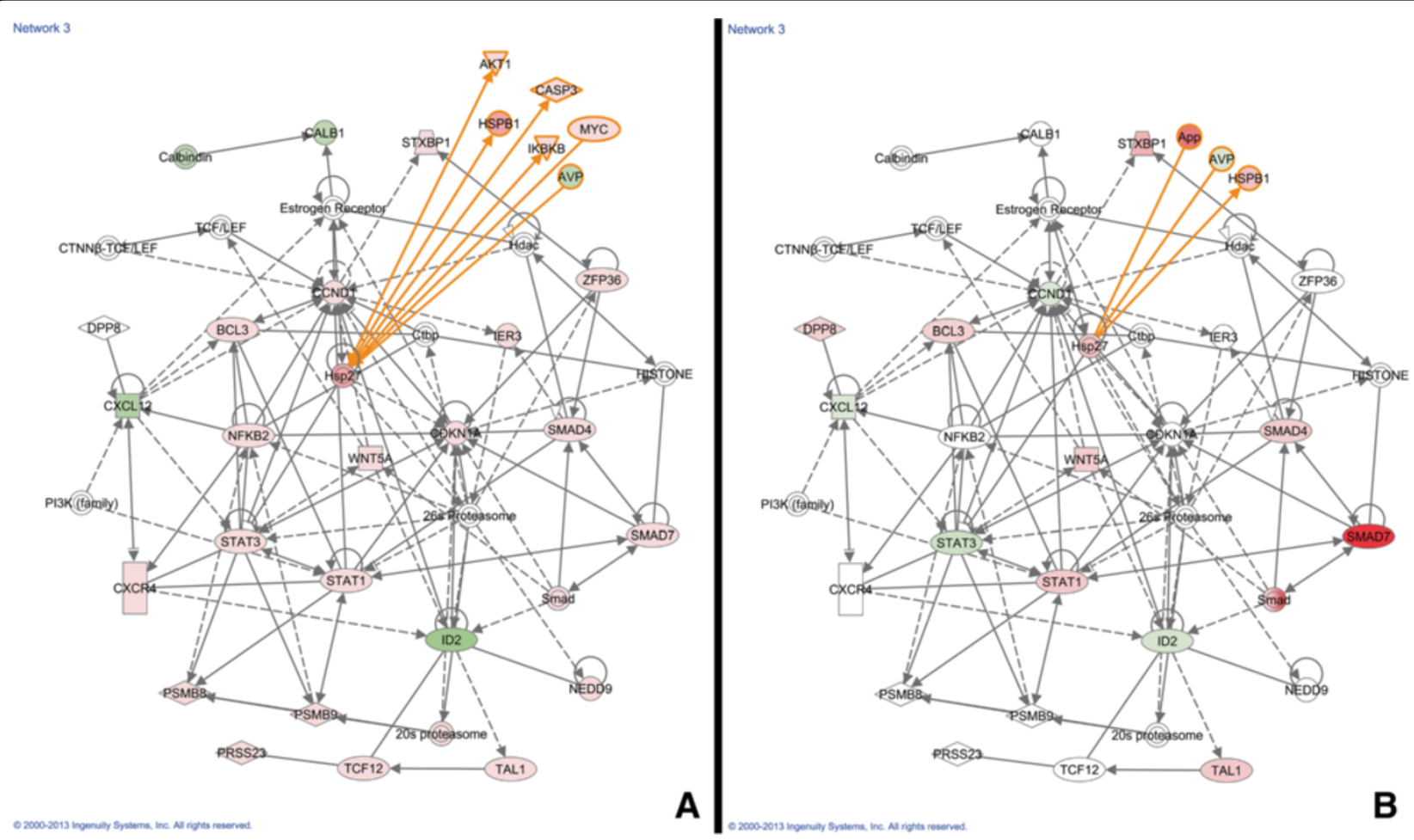

Figure 8 Analysis of a highly scored IPA generated gene network. This gene network was scored in the top three networks associated with the TBI-I/TBI-C union dataset. The relative expression values of all TBI-I IR genes $(\mathbf{A})$ and all TBI-C IR genes $(\mathbf{B})$ included in this network are shown. red: relative increase in expression; green: relative decrease in expression; white: no change in expression; orange connections and outlines: direct connections with gene groups and complexes in the original network. 


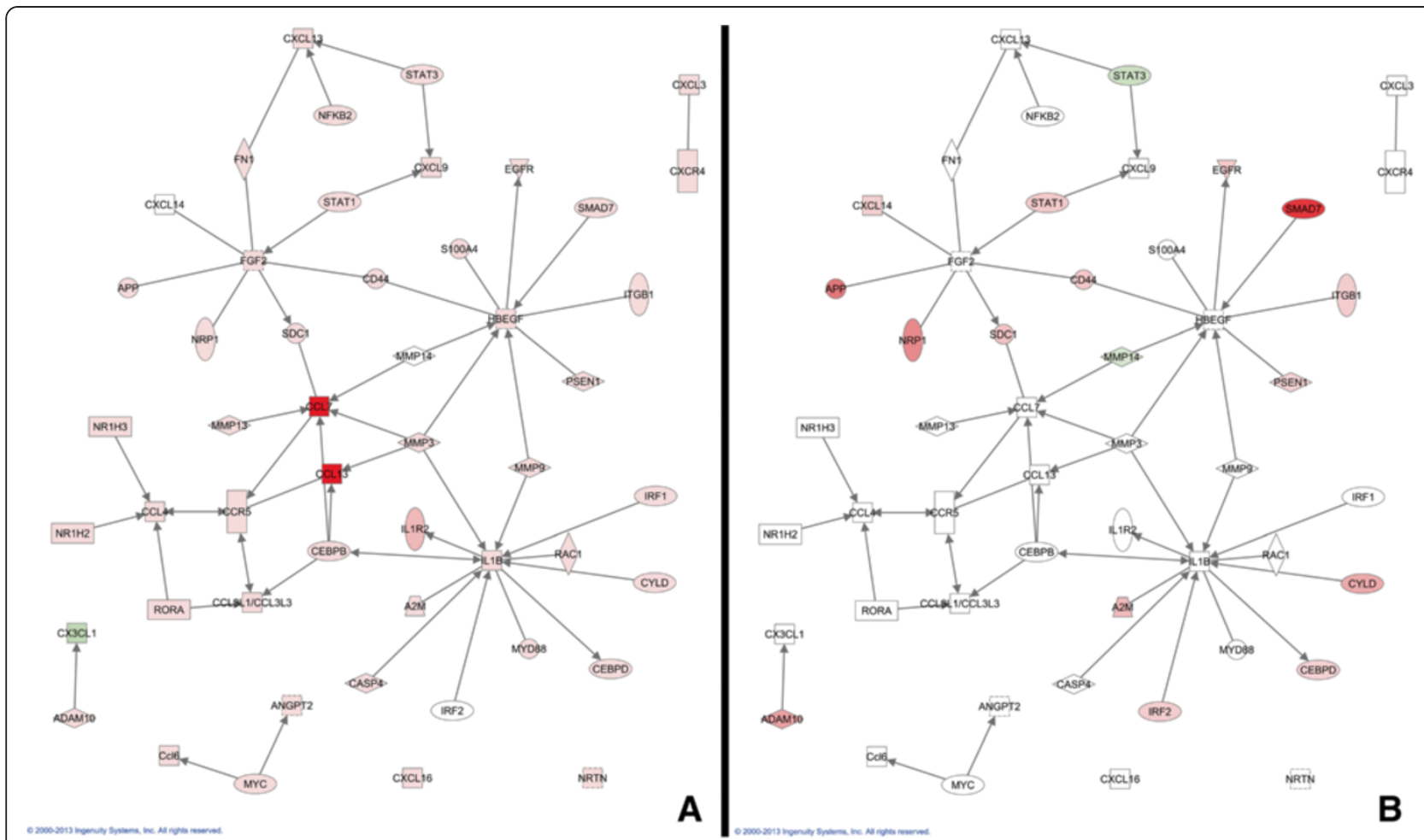

Figure 9 Cytokine and growth factor network analysis. The gene network was created in IPA by seeding with the IR cytokines and growth factors expressed uniquely in the TBI-I analysis and "growing" those genes into a network by showing their direct connections with genes in the union of all TBI-I and TBI-C IR genes dataset. The relative expression values of all TBI-I IR genes (A) and all TBI-C IR genes (B) included in this network are shown. red: relative increase in expression; green: relative decrease in expression; white: no change in expression.

change differently on each side of the brain, we identified 114 GOI. Many of these genes have been previously associated with the IR following ABI's (i.e., TBI, stroke, nerve agent exposure) including CCL13/CCL2, CCL4, CCL6, CCL7, CCR5, CD14, CD44, CDKN1A, CEBPB, CEBPD, CXCL13, CXCL9, CSF1, FOS, HBEGF, HSPA1A/HSPA1B, ICAM1, IER3, IL-1 $\beta$, IRF1, IRF2, JAK2, LCN2, MMP3, MMP9, MYD88, NF-кB, PSMB8, S100A4, SPP1, STAT3, TLR2, TLR4, and TNFRSF1A [10,13,21,24-34]. These results support the utility of our methods for identifying the significant genes related to this biological function. Additionally, several IR genes that appear to be novel in the context of TBI were also identified, providing new targets for future study. These genes included HSP90AA1, ERAP1, PSMB9, CBL, BTK, RORA, THRA, and ITGA5. We wanted to take our analysis one step further and determine which genes were likely the most critical in the observed IR. We accomplished this by creating a network of these genes and determining how many $1^{\text {st }}$ order connections each gene had with the other genes in the network. A GIH was created based on these numbers and there were some intriguing findings in terms of which tier certain molecule types predominated.

Not surprisingly, a large number of transcription regulators were included in the primary and secondary tiers as these molecules are the point of convergence for many of the inflammatory pathways and the regulatory step in the production of new proteins. Somewhat surprising was the large number of cytokines that fell into the peripheral tier since considerable focus has been placed on cytokines as mediators of inflammation and targets for therapeutic intervention $[10,21,24]$. This result may be due to a near 1-to-1 relationship that these cytokines have with their receptors, limiting the $1^{\text {st }}$ order connections in the GOI network. While cytokines clearly play an important role in initiating the IR, they may not be the most critical molecules in modulating the IR. Only one cytokine, IL1B, is in the primary tier of our hierarchy while CCL7, CXCL10, and SPP1 are in the secondary tier. This suggests that neuroprotective strategies directed at one of the lower tier cytokines may not be sufficient for limiting the IR [35]. Further, while therapeutic hypothermia after TBI has been shown to improve outcome, inflammatory cytokine levels were unaffected, implying minimal cytokine involvement in the observed neuroprotection [26]. However, targeting the cytokines in the higher tiers may produce effective modification of the IR [36]. Our GIH shows that regulation of transcription, phosphorylation (kinases), extracellular matrix/cell adhesion (FN1, MMPs, ICAM1), and receptors (transmembrane and G-coupled) figure 
Table 3 Gene interaction hierarchy (GIH)

\begin{tabular}{|c|c|c|c|c|}
\hline Gene symbol & Entrez gene name & $\begin{array}{l}\text { Fold change } \\
\text { (TBI-I | TBI-C) }\end{array}$ & $\begin{array}{c}\text { Cellular } \\
\text { compartment }\end{array}$ & Molecular type \\
\hline \multicolumn{5}{|l|}{ Primary } \\
\hline CEBPB & CCAAT/enhancer binding protein (C/EBP), beta & $3.37 \mid \sim$ & Nucleus & transcription regulator \\
\hline FOS & FBJ murine osteosarcoma viral oncogene homolog & $2.83 \mid \sim$ & Nucleus & transcription regulator \\
\hline IRF1 & interferon regulatory factor 1 & $2.22 \mid \sim$ & Nucleus & transcription regulator \\
\hline IRF7 & interferon regulatory factor 7 & $2.78 \mid \sim$ & Nucleus & transcription regulator \\
\hline MYC & v-myc myelocytomatosis viral oncogene homolog (avian) & $3.96 \mid \sim$ & Nucleus & transcription regulator \\
\hline NFKB2 & $\begin{array}{l}\text { nuclear factor of kappa light polypeptide gene enhancer in B-cells } 2 \\
\text { (p49/p100) }\end{array}$ & $2.77 \mid \sim$ & Nucleus & transcription regulator \\
\hline STAT3 & $\begin{array}{c}\text { signal transducer and activator of transcription } 3 \text { (acute-phase } \\
\text { response factor) }\end{array}$ & $4.22 \mid-3.77$ & Nucleus & transcription regulator \\
\hline EGFR & epidermal growth factor receptor & $6.77 \mid 2.37$ & $\begin{array}{l}\text { Plasma } \\
\text { membrane }\end{array}$ & kinase \\
\hline IKBKB & $\begin{array}{c}\text { inhibitor of kappa light polypeptide gene enhancer in B-cells, kinase } \\
\text { beta }\end{array}$ & $2.13 \mid \sim$ & Cytoplasm & kinase \\
\hline JAK2 & Janus kinase 2 & $2.53 \mid \sim$ & Cytoplasm & kinase \\
\hline LYN & v-yes-1 Yamaguchi sarcoma viral related oncogene homolog & $6.94 \mid 3.78$ & Cytoplasm & kinase \\
\hline FN1 & fibronectin 1 & $3.97 \mid \sim$ & $\begin{array}{l}\text { Extracellular } \\
\text { space }\end{array}$ & enzyme \\
\hline HSP90AA1 & heat shock protein $90 \mathrm{kDa}$ alpha (cytosolic), class A member 1 & $\sim \mid-4.84$ & Cytoplasm & enzyme \\
\hline IL1B & interleukin 1, beta & $5.17 \mid \sim$ & $\begin{array}{l}\text { Extracellular } \\
\text { space }\end{array}$ & cytokine \\
\hline CASP3 & caspase 3, apoptosis-related cysteine peptidase & $2.54 \mid \sim$ & Cytoplasm & peptidase \\
\hline TLR4 & toll-like receptor 4 & $2.70 \mid \sim$ & $\begin{array}{l}\text { Plasma } \\
\text { membrane }\end{array}$ & transmembrane receptor \\
\hline CCND1 & cyclin D1 & $2.15 \mid-2.03$ & Nucleus & other \\
\hline CD44 & CD44 molecule (Indian blood group) & $15.56 \mid 2.40$ & $\begin{array}{l}\text { Plasma } \\
\text { membrane }\end{array}$ & other \\
\hline CDKN1A & cyclin-dependent kinase inhibitor 1A (p21, Cip1) & $2.68 \mid \sim$ & Nucleus & other \\
\hline MYD88 & myeloid differentiation primary response gene (88) & $2.70 \mid \sim$ & $\begin{array}{l}\text { Plasma } \\
\text { membrane }\end{array}$ & other \\
\hline
\end{tabular}

\section{Secondary}

ERAP1

MMP13

MMP14

MMP3

MMP9

PSMB8

PSMB9

ICAM1

IL6R

$$
\text { endoplasmic reticulum aminopeptidase } 1
$$

matrix metallopeptidase 13 (collagenase 3)

matrix metallopeptidase 14 (membrane-inserted)

matrix metallopeptidase 3 (stromelysin 1, progelatinase)

matrix metallopeptidase 9 (gelatinase B, 92 kDa gelatinase, 92 kDa type IV collagenase)

proteasome (prosome, macropain) subunit, beta type, 8 (large multifunctional peptidase 7)

proteasome (prosome, macropain) subunit, beta type, 9 (large multifunctional peptidase 2)

$$
\text { intercellular adhesion molecule } 1
$$

\begin{tabular}{|c|c|c|}
\hline $5.84 \mid 3.05$ & $\begin{array}{l}\text { Extracellular } \\
\text { space }\end{array}$ & peptidase \\
\hline $2.26 \mid \sim$ & $\begin{array}{l}\text { Extracellular } \\
\text { space }\end{array}$ & peptidase \\
\hline$\sim$ | -3.03 & $\begin{array}{l}\text { Extracellular } \\
\text { space }\end{array}$ & peptidase \\
\hline $4.05 \mid \sim$ & $\begin{array}{l}\text { Extracellular } \\
\text { space }\end{array}$ & peptidase \\
\hline $7.18 \mid \sim$ & $\begin{array}{l}\text { Extracellular } \\
\text { space }\end{array}$ & peptidase \\
\hline $3.30 \mid \sim$ & Cytoplasm & peptidase \\
\hline $2.32 \mid \sim$ & Cytoplasm & peptidase \\
\hline $2.60 \mid \sim$ & $\begin{array}{l}\text { Plasma } \\
\text { membrane }\end{array}$ & transmembrane receptor \\
\hline $2.32 \mid \sim$ & Plasma & transmembrane receptor \\
\hline
\end{tabular}

interleukin 6 receptor 
Table 3 Gene interaction hierarchy (GIH) (Continued)

\begin{tabular}{|c|c|c|c|c|}
\hline IL6ST & interleukin 6 signal transducer (gp130, oncostatin M receptor) & $2.31 \mid-3.28$ & $\begin{array}{c}\text { Plasma } \\
\text { membrane }\end{array}$ & transmembrane receptor \\
\hline TLR2 & toll-like receptor 2 & $2.33 \mid \sim$ & $\begin{array}{c}\text { Plasma } \\
\text { membrane }\end{array}$ & transmembrane receptor \\
\hline TNFRSF1A & tumor necrosis factor receptor superfamily, member $1 \mathrm{~A}$ & $3.56 \mid \sim$ & $\begin{array}{c}\text { Plasma } \\
\text { membrane }\end{array}$ & transmembrane receptor \\
\hline$C B L$ & Cas-Br-M (murine) ecotropic retroviral transforming sequence & $-3.40 \mid-6.13$ & Nucleus & transcription regulator \\
\hline CEBPD & CCAAT/enhancer binding protein (C/EBP), delta & $11.27 \mid 2.04$ & Nucleus & transcription regulator \\
\hline IRF2 & interferon regulatory factor 2 & $\sim \mid 2.17$ & Nucleus & transcription regulator \\
\hline IRF9 & interferon regulatory factor 9 & $3.26 \mid \sim$ & Nucleus & transcription regulator \\
\hline CCL7 & chemokine (C-C motif) ligand 7 & $124.78 \mid \sim$ & $\begin{array}{l}\text { Extracellular } \\
\text { space }\end{array}$ & cytokine \\
\hline CXCL10 & chemokine (C-X-C motif) ligand 10 & $\sim \mid-3.29$ & $\begin{array}{c}\text { Extracellular } \\
\text { space }\end{array}$ & cytokine \\
\hline SPP1 & secreted phosphoprotein 1 & $37.91 \mid 2.37$ & $\begin{array}{l}\text { Extracellular } \\
\text { space }\end{array}$ & cytokine \\
\hline AKT1 & v-akt murine thymoma viral oncogene homolog 1 & $2.04 \mid \sim$ & Cytoplasm & kinase \\
\hline BTK & Bruton agammaglobulinemia tyrosine kinase & $2.29 \mid \sim$ & Cytoplasm & kinase \\
\hline EIF2AK2 & eukaryotic translation initiation factor 2-alpha kinase 2 & $2.18 \mid \sim$ & Cytoplasm & kinase \\
\hline CCR5 & chemokine (C-C motif) receptor 5 & $2.09 \mid \sim$ & $\begin{array}{c}\text { Plasma } \\
\text { membrane }\end{array}$ & $\begin{array}{l}\text { G-protein coupled } \\
\text { receptor }\end{array}$ \\
\hline CXCR4 & chemokine (C-X-C motif) receptor 4 & $2.31 \mid \sim$ & $\begin{array}{c}\text { Plasma } \\
\text { membrane }\end{array}$ & $\begin{array}{l}\text { G-protein coupled } \\
\text { receptor }\end{array}$ \\
\hline HBEGF & heparin-binding EGF-like growth factor & $7.07 \mid \sim$ & $\begin{array}{l}\text { Extracellular } \\
\text { space }\end{array}$ & growth factor \\
\hline FGF2 & fibroblast growth factor 2 (basic) & $2.39 \mid \sim$ & $\begin{array}{c}\text { Extracellular } \\
\text { space }\end{array}$ & growth factor \\
\hline RORA & RAR-related orphan receptor A & $2.50 \mid \sim$ & Nucleus & $\begin{array}{l}\text { ligand-dependent } \\
\text { nuclear receptor }\end{array}$ \\
\hline THRA & thyroid hormone receptor, alpha & $-2.80 \mid-11.52$ & Nucleus & $\begin{array}{l}\text { ligand-dependent } \\
\text { nuclear receptor }\end{array}$ \\
\hline RAC1 & $\begin{array}{c}\text { ras-related C3 botulinum toxin substrate } 1 \text { (rho family, small GTP } \\
\text { binding protein Rac1) }\end{array}$ & $2.32 \mid \sim$ & $\begin{array}{l}\text { Plasma } \\
\text { membrane }\end{array}$ & enzyme \\
\hline PTPN6 & protein tyrosine phosphatase, non-receptor type 6 & $3.64 \mid \sim$ & Cytoplasm & phosphatase \\
\hline HSPA1A/HSPA1B & heat shock $70 \mathrm{kDa}$ protein $1 \mathrm{~A}$ & $3.14 \mid \sim$ & Cytoplasm & other \\
\hline ITGA5 & integrin, alpha 5 (fibronectin receptor, alpha polypeptide) & $4.83 \mid 2.68$ & $\begin{array}{l}\text { Plasma } \\
\text { membrane }\end{array}$ & other \\
\hline SDC1 & syndecan 1 & $13.68 \mid 2.57$ & $\begin{array}{l}\text { Plasma } \\
\text { membrane }\end{array}$ & other \\
\hline TIMP1 & TIMP metallopeptidase inhibitor 1 & $38.49 \mid 2.10$ & $\begin{array}{l}\text { Extracellular } \\
\text { space }\end{array}$ & other \\
\hline \multicolumn{5}{|l|}{ Peripheral } \\
\hline CCL13/CCL2 & chemokine ( $\mathrm{C}-\mathrm{C}$ motif) ligand 13/2 & $195.46 \mid \sim$ & $\begin{array}{l}\text { Extracellular } \\
\text { space }\end{array}$ & cytokine \\
\hline CCL3L1/CCL3L3 & chemokine (C-C motif) ligand 3-like 1 & $5.27 \mid \sim$ & $\begin{array}{l}\text { Extracellular } \\
\text { space }\end{array}$ & cytokine \\
\hline CCL4 & chemokine ( $\mathrm{C}-\mathrm{C}$ motif) ligand 4 & $2.16 \mid \sim$ & $\begin{array}{l}\text { Extracellular } \\
\text { space }\end{array}$ & cytokine \\
\hline Ccl6 & chemokine (C-C motif) ligand 6 & $10.29 \mid \sim$ & $\begin{array}{l}\text { Extracellular } \\
\text { space }\end{array}$ & cytokine \\
\hline CSF1 & colony stimulating factor 1 (macrophage) & $3.70 \mid 2.09$ & $\begin{array}{l}\text { Extracellular } \\
\text { space }\end{array}$ & cytokine \\
\hline
\end{tabular}


Table 3 Gene interaction hierarchy (GIH) (Continued)

\begin{tabular}{|c|c|c|c|c|}
\hline CXCL13 & chemokine (C-X-C motif) ligand 13 & $3.78 \mid \sim$ & $\begin{array}{l}\text { Extracellular } \\
\text { space }\end{array}$ & cytokine \\
\hline CXCL14 & chemokine (C-X-C motif) ligand 14 & $\sim \mid 2.13$ & $\begin{array}{l}\text { Extracellular } \\
\text { space }\end{array}$ & cytokine \\
\hline CXCL9 & chemokine (C-X-C motif) ligand 9 & $2.85 \mid \sim$ & $\begin{array}{l}\text { Extracellular } \\
\text { space }\end{array}$ & cytokine \\
\hline CD14 & CD14 molecule & $10.66 \mid \sim$ & $\begin{array}{l}\text { Plasma } \\
\text { membrane }\end{array}$ & transmembrane receptor \\
\hline FCGR2B & Fc fragment of IgG, low affinity Ilb, receptor (CD32) & $5.12 \mid \sim$ & $\begin{array}{l}\text { Plasma } \\
\text { membrane }\end{array}$ & transmembrane receptor \\
\hline$H L A-C$ & major histocompatibility complex, class I, C & $9.30 \mid 3.66$ & $\begin{array}{l}\text { Plasma } \\
\text { membrane }\end{array}$ & transmembrane receptor \\
\hline HLA-DRA & major histocompatibility complex, class II, DR alpha & $2.70 \mid \sim$ & $\begin{array}{l}\text { Plasma } \\
\text { membrane }\end{array}$ & transmembrane receptor \\
\hline IL $1 \mathrm{R} 2$ & interleukin 1 receptor, type ॥ & $37.03 \mid \sim$ & $\begin{array}{l}\text { Plasma } \\
\text { membrane }\end{array}$ & transmembrane receptor \\
\hline $\begin{array}{l}\text { GBP2 (includes } \\
\text { EG:14469) }\end{array}$ & guanylate binding protein 2 , interferon-inducible & $9.13 \mid \sim$ & Cytoplasm & enzyme \\
\hline$M \times 1$ & $\begin{array}{l}\text { myxovirus (influenza virus) resistance 1, interferon-inducible protein } \\
\qquad \text { p78 (mouse) }\end{array}$ & $28.18 \mid 7.33$ & Nucleus & enzyme \\
\hline RALBP1 & ralA binding protein 1 & $2.23 \mid \sim$ & Cytoplasm & enzyme \\
\hline TOP2A & topoisomerase (DNA) II alpha $170 \mathrm{kDa}$ & $2.26 \mid-2.41$ & Nucleus & enzyme \\
\hline EGR2 & early growth response 2 & $2.27 \mid \sim$ & Nucleus & transcription regulator \\
\hline NFE2L2 & nuclear factor (erythroid-derived 2)-like 2 & $2.45 \mid \sim$ & Nucleus & transcription regulator \\
\hline LCN2 & lipocalin 2 & $71.82 \mid 3.90$ & $\begin{array}{l}\text { Extracellular } \\
\text { space }\end{array}$ & transporter \\
\hline RASA1 & RAS p21 protein activator (GTPase activating protein) 1 & $2.39 \mid-2.11$ & Cytoplasm & transporter \\
\hline $\mathrm{NR} 1 \mathrm{H} 2$ & nuclear receptor subfamily 1, group $\mathrm{H}$, member 2 & $2.15 \mid \sim$ & Nucleus & $\begin{array}{l}\text { ligand-dependent } \\
\text { nuclear receptor }\end{array}$ \\
\hline $\mathrm{NR} 1 \mathrm{H} 3$ & nuclear receptor subfamily 1 , group $H$, member 3 & $2.16 \mid \sim$ & Nucleus & $\begin{array}{l}\text { ligand-dependent } \\
\text { nuclear receptor }\end{array}$ \\
\hline HSPB8 & heat shock 22 kDa protein 8 & $4.11 \mid \sim$ & Cytoplasm & kinase \\
\hline RIPK3 & receptor-interacting serine-threonine kinase 3 & $7.55 \mid \sim$ & $\begin{array}{c}\text { Plasma } \\
\text { membrane }\end{array}$ & kinase \\
\hline CASP4 & caspase 4, apoptosis-related cysteine peptidase & $3.05 \mid \sim$ & Cytoplasm & peptidase \\
\hline DPP8 & dipeptidyl-peptidase 8 & $\sim \mid 2.06$ & Cytoplasm & peptidase \\
\hline ANGPT2 & angiopoietin 2 & $2.98 \mid \sim$ & $\begin{array}{c}\text { Extracellular } \\
\text { space }\end{array}$ & growth factor \\
\hline CD63 & CD63 molecule & $2.07 \mid \sim$ & $\begin{array}{c}\text { Plasma } \\
\text { membrane }\end{array}$ & other \\
\hline HSPB1 & heat shock 27 kDa protein 1 & $46.92 \mid 2.64$ & Cytoplasm & other \\
\hline IER3 & immediate early response 3 & $2.35 \mid \sim$ & Cytoplasm & other \\
\hline $\mathrm{IF|} 44$ & interferon-induced protein 44 & $3.12 \mid \sim$ & Cytoplasm & other \\
\hline IFITM3 & interferon induced transmembrane protein 3 & $3.48 \mid \sim$ & $\begin{array}{c}\text { Plasma } \\
\text { membrane }\end{array}$ & other \\
\hline ISG15 & ISG15 ubiquitin-like modifier & $3.53 \mid \sim$ & $\begin{array}{c}\text { Extracellular } \\
\text { space }\end{array}$ & other \\
\hline
\end{tabular}


Table 3 Gene interaction hierarchy (GIH) (Continued)

\begin{tabular}{|c|c|c|c|c|}
\hline NEDD9 & neural precursor cell expressed, developmentally down-regulated 9 & $2.59 \mid \sim$ & Nucleus & other \\
\hline S100A4 & S100 calcium binding protein A4 & $4.73 \mid \sim$ & Cytoplasm & other \\
\hline SERPINA3 & $\begin{array}{l}\text { serpin peptidase inhibitor, clade A (alpha-1 antiproteinase, } \\
\text { antitrypsin), member } 3\end{array}$ & $58.49 \mid 2.51$ & $\begin{array}{l}\text { Extracellular } \\
\text { space }\end{array}$ & other \\
\hline TNFAIP6 & tumor necrosis factor, alpha-induced protein 6 & $3.02 \mid \sim$ & $\begin{array}{l}\text { Extracellular } \\
\text { space }\end{array}$ & other \\
\hline \multicolumn{5}{|l|}{ Orphan } \\
\hline MGLL & monoglyceride lipase & $-7.85 \mid-18.15$ & $\begin{array}{l}\text { Plasma } \\
\text { membrane }\end{array}$ & enzyme \\
\hline MYO9B & myosin IXB & $2.18 \mid \sim$ & Cytoplasm & enzyme \\
\hline PAFAH1B1 & $\begin{array}{l}\text { platelet-activating factor acetylhydrolase } 1 \mathrm{~b} \text {, regulatory subunit } 1 \\
\qquad(45 \mathrm{kDa})\end{array}$ & $\sim \mid-2.86$ & Cytoplasm & enzyme \\
\hline PDE $4 B$ & phosphodiesterase 4B, CAMP-specific & $5.60 \mid 2.36$ & Cytoplasm & enzyme \\
\hline DEK & DEK oncogene & $-3.01 \mid-7.35$ & Nucleus & transcription regulator \\
\hline TCF12 & transcription factor 12 & $2.16 \mid \sim$ & Nucleus & transcription regulator \\
\hline IGSF6 & immunoglobulin superfamily, member 6 & $22.46 \mid 3.27$ & $\begin{array}{l}\text { Plasma } \\
\text { membrane }\end{array}$ & transmembrane receptor \\
\hline THBD & thrombomodulin & $3.85 \mid 2.09$ & $\begin{array}{l}\text { Plasma } \\
\text { membrane }\end{array}$ & transmembrane receptor \\
\hline TGFB2 & transforming growth factor, beta 2 & $-4.00 \mid-7.97$ & $\begin{array}{l}\text { Extracellular } \\
\text { space }\end{array}$ & growth factor \\
\hline KCNN4 & $\begin{array}{l}\text { potassium intermediate/small conductance calcium-activated } \\
\text { channel, subfamily N, member } 4\end{array}$ & $3.09 \mid-9.43$ & $\begin{array}{l}\text { Plasma } \\
\text { membrane }\end{array}$ & ion channel \\
\hline PRSS23 & protease, serine, 23 & $4.05 \mid \sim$ & $\begin{array}{l}\text { Extracellular } \\
\text { space }\end{array}$ & peptidase \\
\hline PTPN4 & protein tyrosine phosphatase, non-receptor type 4 (megakaryocyte) & $4.49 \mid 2.21$ & Cytoplasm & phosphatase \\
\hline CALB1 & calbindin 1, $28 \mathrm{kDa}$ & $-2.09 \mid \sim$ & Cytoplasm & other \\
\hline CLEC12A & C-type lectin domain family 12 , member $A$ & $10.29 \mid 2.15$ & $\begin{array}{l}\text { Plasma } \\
\text { membrane }\end{array}$ & other \\
\hline$\angle C P 1$ & lymphocyte cytosolic protein 1 (L-plastin) & $6.08 \mid 2.80$ & Cytoplasm & other \\
\hline LSP1 & lymphocyte-specific protein 1 & $11.72 \mid 2.14$ & Cytoplasm & other \\
\hline MYOIF & myosin IF & $4.27 \mid 2.26$ & Cytoplasm & other \\
\hline SERPING1 & serpin peptidase inhibitor, clade $\mathrm{G}$ ( $\mathrm{C} 1$ inhibitor), member 1 & $5.81 \mid 2.03$ & $\begin{array}{l}\text { Extracellular } \\
\text { space }\end{array}$ & other \\
\hline $\begin{array}{l}\text { Slpi (includes } \\
\text { others) }\end{array}$ & secretory leukocyte peptidase inhibitor & $82.91 \mid 3.12$ & unknown & other \\
\hline
\end{tabular}

Primary: >10 connections in GOI network (see text); Secondary: 5-10 connections in GOI network;

Peripheral: $<5$ connections in GOI network; Orphan: No connections in GOI network;

Italics $=>$ Gene changes on both sides of the brain; Bold= > Gene changes only contralaterally; All other genes change only ipsilaterally;

prominently (primary and secondary tiers) in the post-TBI IR. These molecules may, therefore, be more efficient targets for therapeutic strategies to combat post-TBI inflammation because they are activated regardless of the initiating factor.

Two well characterized signaling pathways stood out in our GIH: toll-like receptor/NF- $\mathrm{BB}$ signaling and JAK/ STAT signaling. There was some concern that our choice of canonical pathway may have skewed our analysis towards these signaling pathways (toll-like receptor/NF-kB and JAK/STAT) because large portions of both of these pathways are included in IL-6 signaling (Figure 4). While
12 GOI are included in that pathway, 8 of these genes were also identified by other analyses used to identify GOI, further supporting their importance to the post-TBI IR. Additionally, interconnection of the genes in IL-6 signaling could not account for the total number of $1^{\text {st }}$ order connections for these genes in the GOI network used to build the GIH. This was especially true for genes in the primary tier. 19 GOI were either a part of (CEBPB, FOS, NFKB2, EGFR, IKBKB, IL1B, TLR4, MYD88, TLR2, TNFRSF1A, CD14, IL1R2), a product of (IRF1, FN1, CCND1, CASP3), or associated with (IRF7, LYN, HSP90AA1) toll-like receptor/NF- $\mathrm{B}$ signaling 
[8]. 15 of these genes were in the primary tier of the GIH. Secondarily, 5 GOI (JAK2, STAT3, CDKN1A, IL6R, IL6ST) were a part of JAK/STAT signaling [8], and three of these genes were in the primary tier. Based on our analysis, these signaling pathways are likely candidates for the induction of post-TBI IR. Therefore, therapeutic strategies aimed at the molecules in these pathways may reduce TBI-induced inflammation and, by extension, post-TBI neuronal death.

It should be noted that this study only takes a snapshot at 24 hours post-injury of a dynamic and evolving molecular process initiated by TBI [37]. Therefore, significant molecular events that precede and follow this time point are not reflected in these data. For a more complete examination of the molecular response to TBI, a study including multiple time points before and after 24 hours will be necessary and are underway in our laboratory. Further, confirmation of the biological relevance of any observed gene expression profile following TBI is a critical next step to exploring potential therapies for brain trauma $[26,38]$.

\section{Conclusions}

Microarray analysis is a powerful tool that allows for the analysis of thousands of genes simultaneously. We demonstrated that TBI was associated with a powerful proinflammatory response in ipsilateral brain tissues. We also noted the distinct IR gene expression pattern that suggests a remote anti-inflammatory response. The use of multiple network and pathway analyses to identify GOI aided in making our datasets manageable and revealed 2 distinct pathways, toll-like receptor/NF-kB signaling and JAK/ STAT signaling, associated with post-TBI secondary neural injury. Our GIH provides a starting point for investigating therapeutic targets in a ranked order that is somewhat different than what has been presented previously in microarray studies. In addition to being a vehicle for identifying potential targets for post-TBI therapeutic strategies, our GIH can also provide a context for evaluating the potential of therapeutic agents currently in development.

\section{Methods \\ Animals}

All animals used in these studies were treated humanely and with regard for alleviation of suffering and pain and all protocols involving animals were approved by the IACUCs of Morehouse School of Medicine and/or The Georgia Institute of Technology prior to the initiation of experimentation. Adult male Sprague-Dawley rats (290-300 g; Charles River Laboratories International, Inc., USA) were housed individually in standard plastic cages in a temperaturecontrolled room $\left(22 \pm 2^{\circ} \mathrm{C}\right)$ on a $12 \mathrm{~h}$ reverse light-dark cycle. Food and water were provided ad libitum.

\section{Controlled cortical impact}

Under isoflurane anesthesia, rats received a unilateral controlled cortical impact (CCI/TBI) using the Pittsburgh Precision Instruments, Inc. device. A craniotomy was made with the center $4 \mathrm{~mm}$ posterior and 3-4 $\mathrm{mm}$ lateral to bregma using a $6 \mathrm{~mm}$ diameter trephan drill bit. The impact was done at an angle of $15^{\circ}$ from vertical with a velocity of $3 \mathrm{~m} / \mathrm{s}$ to a depth of $2 \mathrm{~mm}$ using a $5 \mathrm{~mm}$ diameter impact tip. The rats were sacrificed $24 \mathrm{~h}$ post-injury and the brains were removed for RNA isolation or histology.

\section{RNA preparation and GeneChip analysis}

The ipsilateral hemi-brain tissue at the site of the injury, the corresponding contralateral hemi-brain tissue, and naïve (control) brain tissue ( $\mathrm{n}=3$ for each) were used for RNA isolation. Total RNA was extracted with TRIzol Reagent (Life Technologies, Rockville, MD, USA) and cleaned (RNAqueous Kit, Ambion, Austin, TX, USA). The RNA was prepared for microarray hybridization with the GeneChip ${ }^{\circledR} 3^{\prime}$ IVT Express Kit (Affymetrix Inc., Santa Clara, CA, USA) aRNA amplification procedure. Briefly, total RNA was reverse transcribed to synthesize first-strand cDNA containing a T7 promoter sequence. The single-stranded cDNA was converted into a doublestranded DNA template for transcription. The reaction employed DNA polymerase and RNase $\mathrm{H}$ to simultaneously degrade the RNA and synthesize second-strand cDNA. In vitro transcription generated multiple copies of biotin-modified aRNA from the double-stranded cDNA templates (this was the amplification step). aRNA Purification removed unincorporated NTPs, salts, enzymes, and inorganic phosphate to improve the stability of the biotin-modified aRNA. Finally, the labeled aRNA was fragmented to prepare the target for hybridization to GeneChip ${ }^{\circledR} 3^{\prime}$ expression arrays [39]. Following fragmentation, $15 \mu \mathrm{g}$ of the biotinylated cRNA was hybridized to an Affymetrix Rat Genome 2302.0 GeneChip. The chips were hybridized at $45^{\circ} \mathrm{C}$ for $16 \mathrm{~h}$, and then washed, stained with streptavidin-phycoerythrin and scanned according to manufacturing guidelines.

\section{Microarray data analysis}

Data analysis was performed using Affymetrix Expression Console $^{\mathrm{TM}}$ software that supports probe set summarization and CHP file generation of $3^{\prime}$ expression using the MAS5 Statistical algorithm. Affymetrix microarrays contain the hybridization, labeling and housekeeping controls that help determine the success of the hybridizations. The Affymetrix Expression Analysis algorithm uses the Tukey's biweight estimator to provide a robust mean Signal value and the Wilcoxon's rank test to calculate a significance or $\mathrm{p}$-value and Detection call for each probe set. The Detection p-value is calculated using a Discrimination Score [R] 
for all probes. The Discrimination Score is a basic property of a probe pair that describes its ability to detect its intended target. It measures the target-specific intensity differences of the probe pair (perfect match (PM) mismatch $(\mathrm{MM})$ ) relative to its overall hybridization intensity $(\mathrm{PM}+\mathrm{MM})$. Background estimation is provided by a weighted average of the lowest $2 \%$ of the feature intensities. Mismatch probes are utilized to adjust the perfect match (PM) intensity. Linear scaling of the feature level intensity values, using the trimmed mean, is the default to make the means equal for all arrays being analyzed. False-negative and false-positive rates are minimized by subtracting nonspecific signal from the PM probe intensities and performing an intensitydependent normalization at the probe set level. Three chips were used for each experimental group: ipsilateral, contralateral and naïve control. The datasets produced by the Affymetrix software contain gene identifiers and corresponding expression values. The datasets used for this study can be accessed in the Gene Expression Omnibus (http://www.ncbi.nlm.nih.gov/geo/) of the National Center for Biotechnology Information (NCBI) with accession number GSE45997. These data were analyzed in Microsoft Excel for calculation of fold change and whether the genes were confirmed as present in the tissue sample (as determined by the Affymetrix software). Genes in the injured brain that increased or decreased in expression by 2-fold or more compared to controls and were present in either all 3 ipsilateral samples or all 3 contralateral samples were identified. The gene datasets that were generated were ipsilateral vs naïve (TBI-I) and contralateral vs naïve (TBI-C) fold changes.

\section{Principal component analysis}

PCA was carried out using the Gene Expression Similarity Investigation Suite software (Genesis; Graz University of Technology). The microarray datasets were analyzed and a matrix was constructed to determine distribution of variants. To compute the principal components (PCs), Genesis calculates the $n$ eigenvalues and their corresponding eigenvectors are calculated from the ( $\mathrm{n} \times \mathrm{n})$ distance matrix using Singular Value Decomposition (SVD), where $\mathrm{n}=$ number of genes [40]. The score for each experimental dataset per PC was determined by multiplying the initial expression value by the Genesis calculated eigenvector for each gene and adding up the resulting values. The scores were plotted on the $\mathrm{X}, \mathrm{Y}$, and $\mathrm{Z}$ axes resulting in a 3D scores plot where the coordinates are (PC1 score, PC2 score, PC3 score).

\section{Ingenuity pathway analysis}

The gene datasets were analyzed using Ingenuity Pathway Analysis (Ingenuity ${ }^{\circledR}$ Systems, www.ingenuity.com) and overlaid onto a global molecular network developed from information contained in the Ingenuity Knowledge Base. Fischer's exact test was used to calculate a p-value determining the probability that each biological function and/or disease assigned to that network is due to chance alone. The functions, canonical pathways, and gene networks that were most significant to the dataset were identified. Gene expression profiles were overlaid on the canonical pathway and gene network figures to reveal similarities and dissimilarities in their gene expression patterns. Gene networks were also created using Ingenuity Knowledge Base to further understand specific interactions between our genes of interest.

\section{TBI-I/TBI-C ratio}

We used the following formulas to calculate the ratio of TBI-I to TBI-C fold changes: (1) Gene increased on both sides: ratio $=(\mathrm{TBI}-\mathrm{I}) /(\mathrm{TBI}-\mathrm{C})$; (2) Gene decreased on both sides: ratio $=1 /[(\mathrm{TBI}-\mathrm{I}) /(\mathrm{TBI}-\mathrm{C})]$; and (3) Gene increased ipsilaterally and decreased contralaterally: ratio $=($ TBI-I $) /-$ $[1 /(\mathrm{TBI}-\mathrm{C})]$.

\section{Histology and immunohistochemistry}

At $24 \mathrm{~h}$ post injury, rats were anesthetized with an intraperitoneal injection of a ketamine:xylazine:acetylpromazine cocktail (50:10:1.67 mg/kg respectively) and perfused transcardially with saline followed by cold $4 \%$ paraformaldehyde solution in PBS for $30 \mathrm{~min}$. Brains were quickly removed and cryoprotected in 30\% sucrose. The brains were then frozen in OCT mounting medium and stored until sectioning. Coronal sections of $20 \mu \mathrm{m}$ thickness were cryosectioned from the perilesional brain area of each animal. Sections were mounted on slides which were stored at $-80^{\circ} \mathrm{C}$ until further processed. Fluoro-Jade ${ }^{\circledR}$ B (FJB; AG310, Millipore, Billerica, MA) labeling was performed as previously described [20]. Immunohistochemical localization of macrophages and activated microglia was performed using antibodies against ED-1 (1:500, MAB1435, Millipore) and CD11b (1:500; CBL1512, Millipore). After rinsing in $0.01 \mathrm{M} \mathrm{PBS}$, sections were blocked with buffer containing 5\% normal goat serum and $0.3 \%$ triton-x 100 for $1 \mathrm{~h}$ at $4^{\circ} \mathrm{C}$ and then incubated for $1 \mathrm{~h}$ at $37^{\circ} \mathrm{C}$ with the primary antibodies. Sections incubated with antibodies to ED-1 and CD11b were washed with PBS and incubated with DyLight 594 and DyLight 488 conjugated goat anti-mouse secondary antibodies, respectively (1:400; Jackson ImmunoResearch Laboratory, West Grove, PA) for $1 \mathrm{~h}$ at room temperature. Negative control sections for immunohistochemistry were incubated with the secondary antibody only (no primary antibodies). A Zeiss microscope equipped with a CCD camera (Carl Zeiss Microimaging Inc, Thornwood, NY) was used to capture digital images of the sections. 


\section{Additional files}

Additional file 1: GOI (genes of interest) network created in IPA. This is the resulting network when IPA connected our $114 \mathrm{GOI}$ using only direct (1st order) connections between the genes. 95 of the GOI formed an interconnected network, leaving 19 "orphan" genes.

Additional file 2: Primary tier example for how direct connections were counted. This figure shows an example of how we calculated the number of direct connections for a gene in our GOI network. In IPA, the gene in question was selected (JAK2 in this example). Then, its direct connections were selected by right clicking on JAK2 and using the "select nearest neighbors" option (highlighted in blue). A list of the selected genes was exported and JAK2 was removed from the list (upper right corner). The remaining genes were counted (15 in this example) and JAK2 was ranked in the gene interaction hierarchy (primary tier) by this number.

\section{Additional file 3: Secondary tier example for how direct}

connections were counted. This figure shows an example of how we calculated the number of direct connections for a gene in our $\mathrm{GOI}$ network. In IPA, the gene in question was selected (IRF2 in this example). Then, its direct connections were selected by right clicking on IRF2 and using the "select nearest neighbors" option (highlighted in blue). A list of the selected genes was exported and IRF2 was removed from the list (upper right corner). The remaining genes were counted ( 7 in this example) and IRF2 was ranked in the gene interaction hierarchy (secondary tier) by this number.

\section{Abbreviations}

CCl: Controlled cortical impact; FJB: Fluoro-Jade B; GIH: Gene interaction hierarchy; GOI: Genes of interest; IPA: Ingenuity Pathway Analysis; IR: Inflammatory response; PCA: Principal component analysis; TBI: Traumatic brain injury; TBI-C: Contralateral vs naïve gene dataset; TBI-I: Ipsilateral vs naïve gene dataset.

\section{Competing interests}

The authors declare that they have no competing interests.

\section{Authors' contributions}

TEW, GDF and BDF were responsible for overall study design and execution. TEW, MCS and MCL were responsible for the animal models, sample preparation and histological analysis. TEW, GDF, ASG and BDF were responsible for carrying out microarray studies and bioinformatic data analysis. The manuscript was written by TEW and BDF. All authors have read and approved the final manuscript.

\section{Acknowledgements}

The authors would like to thank Brock Wester, Kaelin Brewster, and Samantha Simon for their technical assistance. This work was supported by National Institutes of Health (NIH) grants U01 NS 057993 (BDF), U54 NS060659 (BDF), Department of Defense Contract \#W81XWH-10-2-0055 (BDF), the W.M. Keck Foundation (BDF); BRIC NIH grant \#5P20M006131-02 (GDF), Howard Hughes Medical Institute grant \#52006306 (GDF) and PHS Grant (UL1 RR025008, KL2 RR025009 or TL1 RR025010) from the Clinical and Translational Science Award program, NIH, National Center for Research Resources (NCRR) (MCL). The project described was supported by Morehouse School of Medicine Grants Number U54 RR026137, G12RR003034 and S21MD000101 from the NCRR, a component of $\mathrm{NIH}$, and its contents are solely the responsibility of the authors and do not necessarily represent the official views of $\mathrm{NCRR}$ or $\mathrm{NIH}$.

\section{Author details}

'Department of Neurobiology, Neuroscience Institute, Morehouse School of Medicine, 720 Westview Drive SW, Atlanta, GA 30310, USA. ${ }^{2}$ Department of Biology, Morehouse College, 830 Westview Drive SW, Atlanta, GA 30314, USA. ${ }^{3}$ Department of Biomedical Engineering, Georgia Institute of Technology, 313 Ferst Drive, Atlanta, GA 30332, USA.

Received: 16 July 2012 Accepted: 15 April 2013

Published: 25 April 2013

\section{References}

1. Zaloshnja E, Miller T, Langlois JA, Selassie AW: Prevalence of long-term disability from traumatic brain injury in the civilian population of the United States, 2005. J Head Trauma Rehabil 2008, 23(6):394-400.

2. Faul M, Xu L, Wald MM, Coronado VG: Traumatic brain injury in the United States: emergency department visits, hospitalizations and deaths 2002-2006. Atlanta (GA): Centers for Disease Control and Prevention, National Center for Injury Prevention and Control; 2010.

3. Coronado VG, Xu L, Basavaraju SV, McGuire LC, Wald MM, Faul MD, Guzman BR, Hemphill JD: Surveillance for traumatic brain injury-related deathsUnited States, 1997-2007. MMWR Surveill Summ 2011, 60(5):1-32.

4. Selassie AW, Zaloshnja E, Langlois JA, Miller T, Jones P, Steiner C: Incidence of long-term disability following traumatic brain injury hospitalization, United States, 2003. J Head Trauma Rehabil 2008, 23(2):123-131.

5. McIntosh TK, Saatman KE, Raghupathi R, Graham DI, Smith DH, Lee VM, Trojanowski JQ: The Dorothy Russell Memorial Lecture. The molecular and cellular sequelae of experimental traumatic brain injury: pathogenetic mechanisms. Neuropathol App/ Neurobiol 1998, 24(4):251-267.

6. Bramlett HM, Dietrich WD: Pathophysiology of cerebral ischemia and brain trauma: similarities and differences. J Cereb Blood Flow Metab 2004, 24(2):133-150.

7. Loane DJ, Faden Al: Neuroprotection for traumatic brain injury: translational challenges and emerging therapeutic strategies. Trends Pharmacol Sci 2010, 31(12):596-604.

8. Ingenuity ${ }^{\circledR}$ Systems Web Site. Www.ingenuity.com.

9. Morganti-Kossmann MC, Rancan M, Stahel PF, Kossmann T: Inflammatory response in acute traumatic brain injury: a double-edged sword. Curr Opin Crit Care 2002, 8(2):101-105.

10. Ghirnikar RS, Lee YL, Eng LF: Inflammation in traumatic brain injury: role of cytokines and chemokines. Neurochem Res 1998, 23(3):329-340.

11. IPA ${ }^{\oplus}$ Canonical Pathways Overview. http://ingenuity.force.com/ipa/ IPATutorials?id=kA250000000TN3aCAG.

12. Fan L, Young PR, Barone FC, Feuerstein GZ, Smith DH, Mclntosh TK: Experimental brain injury induces expression of interleukin-1[beta] mRNA in the rat brain. Brain Res Mol Brain Res 1995, 30(1):125-130,

13. Rostworowski M, Balasingam V, Chabot S, Owens T, Yong WW: Astrogliosis in the neonatal and adult murine brain post-trauma: elevation of inflammatory cytokines and the lack of requirement for endogenous interferon-gamma. J Neurosci 1997, 17(10):3664-3674.

14. Shojo H, Kaneko Y, Mabuchi T, Kibayashi K, Adachi N, Borlongan CV: Genetic and histologic evidence implicates role of inflammation in traumatic brain injury-induced apoptosis in the rat cerebral cortex following moderate fluid percussion injury. Neuroscience 2010, 171(4):1273-1282.

15. Hang CH, Shi JX, Tian J, Li JS, Wu W, Yin HX: Effect of systemic LPS injection on cortical NF-kappaB activity and inflammatory response following traumatic brain injury in rats. Brain Res 2004, 1026(1):23-32.

16. IPA ${ }^{\circledR}$ Network Generation. http://ingenuity.force.com/ipa/IPATutorials? $i d=k A 250000000 T N B Z C A 4$.

17. Ford G, Xu Z, Gates A, Jiang J, Ford BD: Expression Analysis Systematic Explorer (EASE) analysis reveals differential gene expression in permanent and transient focal stroke rat models. Brain Res 2006, 1071(1):226-236.

18. Xu Z, Ford GD, Croslan DR, Jiang J, Gates A, Allen R, Ford BD: Neuroprotection by neuregulin-1 following focal stroke is associated with the attenuation of ischemia-induced pro-inflammatory and stress gene expression. Neurobiol Dis 2005, 19(3):461-470.

19. $\mathrm{Xu} \mathrm{Z}$, Jiang J, Ford G, Ford BD: Neuregulin-1 is neuroprotective and attenuates inflammatory responses induced by ischemic stroke. Biochem Biophys Res Commun 2004, 322(2):440-446.

20. Li Y, Lein PJ, Liu C, Bruun DA, Tewolde T, Ford G, Ford BD: Spatiotemporal pattern of neuronal injury induced by DFP in rats: a model for delayed neuronal cell death following acute OP intoxication. Toxicol Appl Pharmacol 2011, 253(3):261-269.

21. Israelsson C, Bengtsson H, Kylberg A, Kullander K, Lewen A, Hillered L, Ebendal T: Distinct cellular patterns of upregulated chemokine expression supporting a prominent inflammatory role in traumatic brain injury. J Neurotrauma 2008, 25(8):959-974.

22. Chavarria A, Alcocer-Varela J: Is damage in central nervous system due to inflammation? Autoimmun Rev 2004, 3(4):251-260.

23. Laird MD, Vender JR, Dhandapani KM: Opposing roles for reactive astrocytes following traumatic brain injury. Neurosignals 2008, 16(2-3):154-164. 
24. Di Pietro V, Amin D, Pernagallo S, Lazzarino G, Tavazzi B, Vagnozzi R, Pringle A, Belli A: Transcriptomics of traumatic brain injury: gene expression and molecular pathways of different grades of insult in a rat organotypic hippocampal culture model. J Neurotrauma 2010, 27(2):349-359.

25. Herx LM, Rivest $S$, Yong WW: Central nervous system-initiated inflammation and neurotrophism in trauma: IL-1 beta is required for the production of ciliary neurotrophic factor. J Immunol 2000, 165(4):2232-2239.

26. Kochanek PM, Berger RP, Bayir H, Wagner AK, Jenkins LW, Clark RS Biomarkers of primary and evolving damage in traumatic and ischemic brain injury: diagnosis, prognosis, probing mechanisms, and therapeutic decision making. Curr Opin Crit Care 2008, 14(2):135-141.

27. Khan M, Im YB, Shunmugavel A, Gilg AG, Dhindsa RK, Singh AK, Singh I: Administration of S-nitrosoglutathione after traumatic brain injury protects the neurovascular unit and reduces secondary injury in a rat model of controlled cortical impact. J Neuroinflammation 2009, 6:32.

28. Wang $Q$, Tang $X N$, Yenari MA: The inflammatory response in stroke. J Neuroimmunol 2007, 184(1-2):53-68.

29. Kong $Y$, Le Y: Toll-like receptors in inflammation of the central nervous system. Int Immunopharmacol 2011, 11(10):1407-1414.

30. Rall JM, Matzilevich DA, Dash PK: Comparative analysis of mRNA levels in the frontal cortex and the hippocampus in the basal state and in response to experimental brain injury. Neuropathol Appl Neurobiol 2003, 29(2):118-131.

31. Fahlenkamp AV, Coburn M, Czaplik M, Ryang YM, Kipp M, Rossaint R, Beyer C: Expression analysis of the early chemokine response $4 \mathrm{~h}$ after in vitro traumatic brain injury. Inflamm Res 2011, 60(4):379-387.

32. von Gertten C, Flores MA, Holmin S, Mathiesen T, Nordqvist AC: Genomic responses in rat cerebral cortex after traumatic brain injury. BMC Neurosci 2005, 6:69.

33. Kobori N, Clifton GL, Dash P: Altered expression of novel genes in the cerebral cortex following experimental brain injury. Brain Res Mol Brain Res 2002, 104(2):148-158.

34. Poulsen CB, Penkowa M, Borup R, Nielsen FC, Caceres M, Quintana A, Molinero A, Carrasco J, Giralt M, Hidalgo J: Brain response to traumatic brain injury in wild-type and interleukin-6 knockout mice: a microarray analysis. J Neurochem 2005, 92(2):417-432.

35. Ley EJ, Clond MA, Singer MB, Shouhed D, Salim A: IL6 deficiency affects function after traumatic brain injury. J Surg Res 2011, 170(2):253-256.

36. Clausen F, Hanell A, Bjork M, Hillered L, Mir AK, Gram H, Marklund N: Neutralization of interleukin-1 beta modifies the inflammatory response and improves histological and cognitive outcome following traumatic brain injury in mice. Eur J Neurosci 2009, 30(3):385-396.

37. Feuerstein GZ, Wang X, Barone FC: Inflammatory gene expression in cerebral ischemia and trauma. Potential new therapeutic targets. Ann N Y Acad Sci 1997, 825:179-193.

38. Li HH, Lee SM, Cai Y, Sutton RL, Hovda DA: Differential gene expression in hippocampus following experimental brain trauma reveals distinct features of moderate and severe injuries. J Neurotrauma 2004, 21(9):1141-1153.

39. Affymetrix: GeneChip ${ }^{\circledR} 3^{\prime}$ IVT Express Kit User Manual. In vol. P/N 702646 Rev. 8. 2010. http://www.affymetrix.com/support/technical/manuals.affx.

40. Sturn A, Quackenbush J, Trajanoski Z: Genesis: cluster analysis of microarray data. Bioinformatics 2002, 18(1):207-208.

\section{Submit your next manuscript to BioMed Central and take full advantage of:}

- Convenient online submission

- Thorough peer review

- No space constraints or color figure charges

- Immediate publication on acceptance

- Inclusion in PubMed, CAS, Scopus and Google Scholar

- Research which is freely available for redistribution 